\title{
Mechanisms of seawater acclimation in a primitive, anadromous fish, the green sturgeon
}

\author{
Peter J. Allen · Joseph J. Cech Jr · Dietmar Kültz
}

Received: 23 March 2009/Revised: 21 May 2009/ Accepted: 22 May 2009/Published online: 11 June 2009

(C) The Author(s) 2009. This article is published with open access at Springerlink.com

\begin{abstract}
Relatively little is known about salinity acclimation in the primitive groups of fishes. To test whether physiological preparative changes occur and to investigate the mechanisms of salinity acclimation, anadromous green sturgeon, Acipenser medirostris (Chondrostei) of three different ages (100, 170, and $533 \mathrm{dph}$ ) were acclimated for 7 weeks to three different salinities $(<3,10$, and 33 ppt). Gill, kidney, pyloric caeca, and spiral intestine tissues were assayed for $\mathrm{Na}^{+}, \mathrm{K}^{+}$-ATPase activity; and gills were analyzed for mitochondria-rich cell (MRC) size, abundance, localization and $\mathrm{Na}^{+}, \mathrm{K}^{+}$-ATPase content. Kidneys were analyzed for $\mathrm{Na}^{+}, \mathrm{K}^{+}$-ATPase localization and the gastrointestinal tract (GIT) was assessed for changes in ion and base content. $\mathrm{Na}^{+}, \mathrm{K}^{+}$-ATPase activities increased in the gills and decreased in the kidneys with increasing salinity. Gill MRCs increased in size and decreased in relative abundance with fish size/age. Gill MRC $\mathrm{Na}^{+}, \mathrm{K}^{+}$-ATPase content (e.g., ion-pumping capacity) was proportional to MRC size, indicating greater abilities to regulate ions with size/age. Developmental/ontogenetic changes were seen in the rapid increases in gill MRC size and lamellar length between 100 and $170 \mathrm{dph}$. $\mathrm{Na}^{+}, \mathrm{K}^{+}$-ATPase activities increased fourfold in the pyloric caeca in $33 \mathrm{ppt}$, presumably due to increased salt and water absorption as indicated
\end{abstract}

Communicated by G. Heldmaier.

P. J. Allen $(\bowtie) \cdot$ J. J. Cech Jr

Department of Wildlife, Fish, and Conservation Biology,

University of California, 1 Shields Avenue, Davis,

CA 95616, USA

e-mail: pallen@cfr.msstate.edu

D. Kültz

Department of Animal Science, University of California,

1 Shields Avenue, Davis, CA 95616, USA by GIT fluids, solids, and ion concentrations. In contrast to teleosts, a greater proportion of base $\left(\mathrm{HCO}_{3}{ }^{-}\right.$and $\left.2 \mathrm{CO}_{3}{ }^{2-}\right)$ was found in intestinal precipitates than fluids. Green sturgeon osmo- and ionoregulate with similar mechanisms to more-derived teleosts, indicating the importance of these mechanisms during the evolution of fishes, although salinity acclimation may be more dependent on body size.

Keywords $\mathrm{Na}^{+}, \mathrm{K}^{+}$-ATPase $\cdot \mathrm{Cl}^{-} / \mathrm{HCO}_{3}{ }^{-}$exchange . Pyloric caeca · Mitochondria rich cell · Green sturgeon . Acipenser medirostris

$\begin{array}{ll}\text { Abbreviations } \\ \text { BL } & \text { Base of lamellae } \\ \text { BML } & \text { Bodega Marine Laboratory } \\ \text { BW } & \text { Brackish water } \\ \text { dph } & \text { Days post-hatch } \\ \text { F } & \text { Filament } \\ \text { FW } & \text { Fresh water } \\ \text { GIT } & \text { Gastrointestinal tract } \\ \text { ID } & \text { Interlamellar distance } \\ \text { IHC } & \text { Immunohistochemistry } \\ \text { LSC } & \text { Laser-scanning cytometry } \\ \text { MRC } & \text { Mitochondria-rich cell } \\ \text { PBS } & \text { Phosphate-buffered saline } \\ \text { ppt } & \text { Parts per thousand } \\ \text { TL } & \text { Total length } \\ \text { SW } & \text { Seawater }\end{array}$

Introduction

The mechanisms of salinity acclimation and ion and osmoregulation have received a considerable amount of 
study in anadromous fishes. In salmonids, probably the most-studied group of anadromous fishes, the seawater (SW)-adaptive process has been well described and is known as smoltification. Smoltification is characterized by rapid morphological, physiological, and behavioral changes that are mediated by endogenous hormones (Boeuf 1993; Folmar and Dickhoff 1980; Hoar 1988). During this phase, freshwater (FW) salmonids undergo what is in many respects a secondary metamorphosis, with pre-adaptive changes occurring prior to SW exposure in the gills and intestine that allow these fish to osmo- and ionoregulate in hyperosmotic environments. However, there has been very little study on how this process occurs in other anadromous species. Many anadromous species are representatives of more primitive taxa (McDowall 1988, 1997). Aspects of the early life stages of more primitive anadromous fishes are not well-understood (McCormick et al. 1997). In particular, the mechanisms of salinity acclimation, and ion and osmoregulation are not well known (Wright 2007).

The sturgeons are a group of anadromous fishes that are members of a phylogenetically ancient group, infraclass Chondrostei, order Acipenseriformes, diverging from modern teleosts approximately 200 million years ago (Grande and Bemis 1991). A trait of this group of fishes appears to be diadromy (McDowall 1988) with a several species moving to full-strength seawater as a part of their life history. The green sturgeon, Acipenser medirostris, located on the west coast of North America (Moyle 2002), appears to be one of the most anadromous species of the sturgeons (Allen and Cech 2007). This species moves into seawater at a young age (Allen et al. 2009), making it a good candidate for understanding salinity acclimation in this group of fishes. Information on the mechanisms utilized by primitive fishes such as sturgeons to transition into hyperosmotic salinities can broaden understanding of how adaptive strategies have changed or converged over time. In teleosts, a suite of changes in several osmoregulatory structures enables continued ion and osmotic homeostasis as fish move between hypo- and hyper-osmotic salinities (Marshall and Grosell, 2006). $\mathrm{Na}^{+}, \mathrm{K}^{+}$-ATPase plays an important role in the facilitation of ionic and osmotic gradients necessary for ion uptake, excretion and general homeostasis in these tissues. For example, in salmonids, gill (Hoar 1988), pyloric caeca and intestine (Sundell et al. 2003; Veillette and Young 2004) $\mathrm{Na}^{+}, \mathrm{K}^{+}$-ATPase activities have been shown to increase during smoltification, although kidney $\mathrm{Na}^{+}, \mathrm{K}^{+}$-ATPase activity has been shown to decline (McCartney 1976) or not change (Ewing and Rodgers 1998; Madsen et al. 1995). In the gills of most teleosts, $\mathrm{Na}^{+}, \mathrm{K}^{+}$-ATPase activities are the highest in the basolateral plasma membrane of mitochondria-rich cells (MRCs; Wilson and Laurent, 2002), also named chloride cells due to their role in chloride excretion in hyperosmotic environments (Keys and Willmer 1932). MRCs have often been identified based on their role in either ion excretion or ion absorption (Pisam and Rambourg 1991), as well as by apical membrane morphology (Lee et al. 1996). In teleosts, the location and size of MRCs can vary considerably between species (Evans et al. 2005). In many species, ionexcretory MRCs tend to be larger, are located primarily on gill filaments and increase in abundance in hyperosmotic conditions (Mizuno et al. 2000; Pisam et al. 1988; Uchida et al. 1996). Whereas, ion-uptake MRCs are often smaller, located on both the filament and lamellae (Hwang and Lee 2007; Laurent et al. 2006), and decrease in abundance on the lamellae in hyperosmotic conditions (Mizuno et al. 2000; Pisam et al. 1988; Uchida et al. 1996). Many of these mechanisms have been studied in relation to salinity transition; however, fewer studies have been conducted in relation to differences in body size (McCormick 1995).

In sturgeons, $\mathrm{Na}^{+}, \mathrm{K}^{+}$-ATPase activity has been shown to increase in gills in hyperosmotic environments (Krayushkina et al. 2006; McKenzie et al. 1999; Rodriguez et al. 2002), except in shortnose sturgeon (A. brevirostrum; Jarvis and Ballantyne 2003), and either decrease or show no change in the kidneys (Krayushkina et al. 2006) and spiral intestine (Jarvis and Ballantyne 2003; Rodriguez et al. 2002). Pyloric caeca $\mathrm{Na}^{+}, \mathrm{K}^{+}$-ATPase activities in relation to salinity have not been studied in sturgeons. In hyperosmotic environments, MRCs have been shown to be located predominantly on the gill filaments (Cataldi et al. 1995) and increase in number and size (Altinok et al. 1998; Carmona et al. 2004), although overall MRC number has also been found to decline (Cataldi et al. 1995; McKenzie et al. 1999). In hyposmotic environments, MRCs are located on both the lamellae and filaments (Cataldi et al. 1995; McKenzie et al. 1999). $\mathrm{Na}^{+}, \mathrm{K}^{+}, 2 \mathrm{Cl}^{-}$cotransporters also play a role in salinity acclimation, increasing in hyperosmotic salinities (Sardella and Kültz 2008). Other osmoregulatory tissues have also received limited study in sturgeons. In hyperosmotic salinities, no structural changes in the esophageal or intestinal epithelium were found by light microscopy, when compared with hyposmotic salinities (Cataldi et al. 1995). Whereas in the kidney, there have been observations of reduced glomerular size and vascularization (Cataldi et al. 1995), reduced proximal tubule diameter and increased distal tubule diameter (Krayushkina et al. 1996). Surprisingly, there have been few studies to isolate the timing and mechanisms of SW adaptation in sturgeons and the possible presence of a rapid period of pre-adaptive change such as smoltification. However, existing studies indicate that the process of salinity acclimation may be based largely on body size (Allen and Cech 2007; Altinok et al. 1998). Therefore, our objectives were to identify the structures and mechanisms used by green sturgeon for osmo- and ionoregulation and to 
compare them to known mechanisms in teleosts fishes. Based on the limited information available for sturgeons, we initially hypothesized that enzymatic and cellular changes would parallel those in the more derived teleosts.

\section{Materials and methods}

Salinity acclimation (Experiment 1: 100, 170, and $533 \mathrm{dph}$ groups)

Adult wild green sturgeon (Acipenser medirostris Rafinesque) from the Klamath River were spawned and hatched according to the methods described by Van Eenennaam et al. (2001). Three ages $(100,170$, and $533 \mathrm{dph})$ of firstgeneration juveniles were acclimated to either FW ( $<3 \mathrm{ppt}$ ), brackish water (BW; $10 \mathrm{ppt}$ ), or SW (33 ppt; see Allen and Cech 2007). These ages were chosen, based on the results of salinity tolerance experiments (Allen 2005), in order to capture the timing of SW readiness. The salinity tolerance experiments showed that green sturgeon at $100 \mathrm{dph}$ may have difficulty in maintaining plasma osmotic homeostasis and may not survive for extended periods in SW, but at $170 \mathrm{dph}$, they can survive for up to 28 days in SW; thus, any changes that may be taking place may be captured by these two age groups. The $533 \mathrm{dph}$ fish served as a much older group to determine if the fish at $170 \mathrm{dph}$ were fully acclimated for SW life.

The 100 and $170 \mathrm{dph}$ fish were from the same cohort, and the $533 \mathrm{dph}$ fish were from the previous years' cohort. For the 100, 170 and 533 dph groups, initial mean $( \pm \mathrm{SE})$ total lengths were: $18.3 \pm 0.2 \mathrm{~cm}, 34.3 \pm 0.3 \mathrm{~cm}$, and $75.2 \pm 0.7 \mathrm{~cm}$, and initial mean $( \pm \mathrm{SE})$ wet masses were: $23.7 \pm 0.8 \mathrm{~g}, 145.7 \pm 3.8 \mathrm{~g}$, and $1,539 \pm 46 \mathrm{~g}$, respectively. All fish that were in treatments other than FW were gradually acclimated at a rate of 5 ppt $24 \mathrm{~h}^{-1}$, taking SW fish 7 days to reach 33 ppt. Fish were also acclimated to $12-13^{\circ} \mathrm{C}$, the $\mathrm{SW}$ temperature, at $1{ }^{\circ} \mathrm{C}$ day ${ }^{-1}$ from preexperimental conditions at $19^{\circ} \mathrm{C}$. Once the $\mathrm{SW}$ treatment group had reached its final salinity, all fish were held at their treatment salinities for an additional 44-53 days before completion of the experiment.

The $100 \mathrm{dph}$ fish were divided into groups of 30 fish per salinity, and held at the Center for Aquatic Biology and Aquaculture on the University of California, Davis campus. During salinity and temperature adjustments, fish treatment groups were held in separate 50-1 containers that were aerated and situated in temperature controlled water baths. After the SW group reached $33 \mathrm{ppt}$, all fish were transferred to holding tanks. FW fish were held in an insulated 220-1, rectangular fiberglass tank, with a chilled, flowthrough, non-chlorinated, well-water supply. BW and SW fish were held in separate re-circulating systems, each with an identical holding tank. The 170 and 533 dph fish were divided into groups of 30 and 20 fish, respectively, and held at the University of California, Davis, Bodega Marine Laboratory (BML). Both age groups were held together in each of the three salinities in 2-m diameter, 2,000-1 circular fiberglass tanks. The FW tank received flow-through chilled well water, the SW tank received flow-through ambient $\mathrm{SW}$, and the BW tank received a mixture of the two.

Temperature in exposure tanks was monitored every $15 \mathrm{~min}$ by submersible temperature loggers. Salinity (salinity refractometer or YSI 85), dissolved oxygen (YSI 55 or YSI 85), $\mathrm{pH}$, and ammonia (salicylate method, colorimetric kit) were also measured daily. For the $100 \mathrm{dph}$ re-circulating systems, ammonia levels were kept low through daily water changes (15\% of each system's volume) with filtered SW or diluted SW brought in from the BML. In addition, an ammonia detoxifier (Amquel) was also added periodically at manufacturer's recommended dosages to keep ammonia levels low $\left(<20 \mu \mathrm{g} \mathrm{NH}_{3} \mathrm{l}^{-1}\right)$, and wastes and uneaten food were removed by siphon twice daily. All tanks were on a simulated natural (100 dph) or natural photoperiod (170 and $533 \mathrm{dph}$ ), and fish were fed commercial diet (Nelson \& Sons, Inc., Murray, UT, USA; Silver Cup Trout Diet) at 2.4, 1.54, or $0.59 \%$ body mass day ${ }^{-1}$ for the 100,170 , or $533 \mathrm{dph}$ groups, respectively, according to an optimal growth curve based on body mass and temperature that was derived for white sturgeon (A. transmontanus; S. I. Doroshov unpublished data). Fish were fed during crepuscular and nighttime periods via 12 -h belt feeders to maximize food consumption when they were active and searching for food (Kynard et al. 2005).

\section{Salinity acclimation (Experiment 2: $100 \mathrm{dph}$ group} repeated)

A second, similar acclimation experiment was conducted for a separate group of fish that were $100 \mathrm{dph}$ (Experiment 2). Experiment 2 was run because different methodology was used for the original $100 \mathrm{dph}$ group as compared to the two older groups for cell dissociation techniques (see methods below). Therefore, the Experiment 2100 dph group replaced the original $100 \mathrm{dph}$ group for cell dissociation data only. Experiment 2 design was similar to Experiment 1, except that there were $15 \mathrm{fish} / \mathrm{salinity}$, and the SW group was held at 10 ppt for 23 days prior to increasing salinity further. Fish initial weights (mean \pm SEM: $42.37 \pm 2.50 \mathrm{~g}$ ) and total lengths $(215 \pm 4 \mathrm{~mm})$ were slightly larger than Experiment 1 fish at this age.

Fish sampling

At the completion of each experiment, all fish were overdosed in $500 \mathrm{mg}^{-1} \mathrm{MS}-222$, and then quickly $(<5 \mathrm{~min})$ 
weighed, measured, and sampled. To flush erythrocytes from the gills and other tissues (a source of possible $\mathrm{Na}^{+}$, $\mathrm{K}^{+}$-ATPase activity or staining not related to MRCs), fish were perfused with phosphate-buffered saline (PBS; $2.7 \mathrm{mM} \mathrm{KCl}, 1.5 \mathrm{mM} \mathrm{KH}_{2} \mathrm{PO}_{4}, 137.9 \mathrm{mM} \mathrm{NaCl}, 8.1 \mathrm{mM}$ $\mathrm{Na}_{2} \mathrm{HPO}_{4}, \mathrm{pH}$ 7.4). Briefly, fish were placed supine on a surgery table, and the pericardial cavity was exposed via incision. Flexible polyethylene tubing with a hypodermic needle tip was inserted into the conus arteriosus, and PBS was pumped orthograde into the heart via a peristaltic pump. Immediately after starting the perfusion, the sinus venosus and caudal vein were severed to release vascular pressure and allow the fish to exsanguinate.

After perfusion, tissue samples were excised from the gills, kidney, pyloric caeca, and spiral intestine (containing all tissue layers of the outer intestinal wall: mucosal epithelium to serosa), rinsed briefly in PBS, and stored using one of the following methods. For tissue homogenate $\mathrm{Na}^{+}$, $\mathrm{K}^{+}$-ATPase activity determination, approximately $0.1-$ $0.5 \mathrm{~g}$ of tissue (for gill tissue: filaments on the right first arch) was placed into $400 \mu \mathrm{l}$ ice-cold SEI homogenization buffer (McCormick 1993) in a 2-ml microcentrifuge vial and flash frozen in liquid $\mathrm{N}_{2}$ and stored $<3$ months at $-80^{\circ} \mathrm{C}$. For gill cell dissociation, the left second gill arch was removed and immersed in 1:50 w/v ice-cold PBS with $10 \mathrm{mM}$ glucose. For immunohistochemistry (IHC), 1-5 g of tissue samples (for gill samples the first left arch was collected) were immersed in a 1:50 w/v phosphate buffered formalin fixative $(100 \mathrm{ml}$ formaldehyde, $900 \mathrm{ml}$ deionized water, $\left.4 \mathrm{~g} \mathrm{NaH}_{2} \mathrm{PO}_{4} \cdot \mathrm{H}_{2} \mathrm{O}, 6.5 \mathrm{~g} \mathrm{Na}_{2} \mathrm{HPO}_{4}\right)$.

\section{$\mathrm{Na}^{+}, \mathrm{K}^{+}$-ATPase localization by IHC}

$\mathrm{Na}^{+}, \mathrm{K}^{+}$-ATPase localization in the gills and kidney were determined by laser-scanning cytometry (LSC) on samples from Experiment 1 that were fixed and stained using IHC techniques. Gill arches were cut away from gill filaments using a scalpel and forceps after fixation in phosphatebuffered formalin, and all tissue samples were infiltrated with paraplast (Paraplast X-TRA, Fisher Scientific, Pittsburgh, PA, USA) using a vacuum-infiltration processor (Tissue-Tek VIP5, Sakura Finetek USA, Inc., Torrance, CA, USA), and embedded into paraffin (Tissue Prep 2, Fisher) using a tissue-embedding system (Tissue-Tek TEC, Sakura). Samples ( $n=5 /$ salinity/age) were then sectioned to $5 \mu \mathrm{m}$ on a microtome (Bromma 2218 Historange, LKB, Uppsala, Sweden).

Sections were placed on poly-L-lysine coated slides and dried overnight at $40^{\circ} \mathrm{C}$. Sections were then cleared in xylene, dehydrated in an ethanol gradient, and re-hydrated in PBS. Sections were then blocked by incubating in PBS and $1 \%$ BSA (PBA) for $30 \mathrm{~min}$, and then in PBA and $2 \%$ goat serum for $30 \mathrm{~min}$. Primary antibody, mouse anti-avian $\mathrm{Na}^{+}, \mathrm{K}^{+}$-ATPase $\alpha$-subunit, was obtained from the Developmental Studies Hybridoma Bank instituted under the auspices of National Institute for Child Health and Human Development (NICHD) and maintained by the University of Iowa, Department of Biological Sciences, Iowa City, IA 52242, USA. The antibody was diluted in PBA to a final concentration of $6 \mu \mathrm{g} \mathrm{ml}^{-1}$ and the slides were incubated at room temperature for $30 \mathrm{~min}$, and then overnight at $4^{\circ} \mathrm{C}$. Slides were then rinsed in PBS, and incubated with the secondary antibody, goat anti-mouse IgG antibody covalently bound to Alexa 488 (A11029, Invitrogen, Carlsbad, CA, USA) for gill samples at a concentration of $20 \mu \mathrm{g} \mathrm{ml}^{-1}$ in PBA with 1:100 RNase A and Pacific Blue (P-10993, Molecular Probes, Eugene, OR, USA) for kidney samples at a concentration of $20 \mu \mathrm{g} \mathrm{ml}^{-1}$ in PBA for $60 \mathrm{~min}$ at room temperature in the dark. Slides were then rinsed in PBS, counterstained with propidium iodide, rinsed again in PBS, treated with Vectashield (Vector Laboratories, Burlingame, CA, USA), and analyzed immediately $(<1.5 \mathrm{~h})$. Control slides for each tissue were also made with normal mouse serum and secondary antibody, primary antibody only, secondary antibody only, and neither primary nor secondary antibody. Sections were quantified using an LSC with a $40 \times$ objective (UPlanFL/ $40 x / 0.75 / \infty / 0.17$, Olympus) in combination with a LSC UV laser $(400 \mathrm{~nm})$. Contouring and event segmentation variables were adjusted for optimal detection of MRCs and immunofluorescent regions as identified by high fluorescence using WinCyte software (v.3.6, Compucyte, Westwood, MA, USA). For each immunofluorescent area detected, we recorded the area and fluorescence integral using WinCyte software. In gills, each fluorescent region represents a MRC, as the LSC is optimized to separate out each MRC into a discrete stained region (fluorescent integral). Therefore, the $\mathrm{Na}^{+}, \mathrm{K}^{+}$-ATPase concentration per MRC could be determined.

Gill images were captured on the LSC and subsequently MRCs and associated gill morphology were measured using photoimaging software (Adobe Photoshop v.7.0). For each fish ( $n=5$ fish/salinity/age), 20 filament interlamellar distances were measured and filament MRCs were counted (consisting of at least two different filaments), 20 lamellae were measured and MRCs counted, and MRCs from the base of 20 lamellae were counted, based on a set length of $50 \mu \mathrm{m}$ that was determined from initial analyses on fish of different ages.

Kidney samples (15 samples/salinity) were also visually compared for $\mathrm{Na}^{+}, \mathrm{K}^{+}$-ATPase staining location between different salinities, because the location of $\mathrm{Na}^{+}, \mathrm{K}^{+}$ATPase staining did not appear to change with age between visually analyzed samples. 
MRC size and abundance (cell dissociation)

Gills ( $n=6-9 /$ salinity/age) from Experiment 1 for 170 and $533 \mathrm{dph}$ groups, and Experiment 2 for the $100 \mathrm{dph}$ group, that were stored in ice-cold PBS with $10 \mathrm{mM}$ glucose were analyzed within $8 \mathrm{~h}$. Each excised gill arch was placed in a petri dish with $1.0-3.0 \mathrm{ml}$ of PBS, and the gill epithelium was removed from the arch using a scalpel with a scraping motion parallel to the direction of the primary filaments. The cartilaginous gill arch was then rinsed with $1.0-2.0 \mathrm{ml}$ of PBS into the Petri dish to capture any remaining cells. The cell and filament bit mixture was then resuspended in the Petri dish using a plastic transfer pipette. Cells were dissociated by gentle pressure through a stainless-steel 50-mesh screen and then a 200-mesh screen using a ceramic pestle and then rinsed with 10-30 $\mathrm{ml}$ PBS (depending on the size of the fish) into a 15 or $50 \mathrm{ml}$ Falcon tube, following the methods of Kültz and Somero (1995). Cell suspensions were stained with $10 \mu \mathrm{mol} \mathrm{l}^{-1}$ 4-([4-dimethylamino] styryl)- $N$-methyl pyridium iodide (DASPMI) at $4{ }^{\circ} \mathrm{C}$ for $30 \mathrm{~min}$, and then centrifuged at $500 \mathrm{~g}$ for $2 \mathrm{~min}$. The supernatant was then discarded, and $5.0 \mathrm{ml}$ of PBS was added to $15-\mathrm{ml}$ Falcon tubes, and $9.0 \mathrm{ml}$ of PBS was added to 50-ml Falcon tubes. The pellet was gently resuspended and washed using a $1,000-\mu$ pipette or a $5,000-\mu l$ pipette. Falcon tubes were then re-centrifuged for $1 \mathrm{~min}$ at $500 \mathrm{~g}$. Supernatant was removed and discarded, and the pellet was resuspended in $500 \mu \mathrm{l}$ of PBS. The volume of the pellet was then determined by aspirating the exact volume of the resuspended cell mixture using a 1,000- $\mu$ l pipette. For the $170 \mathrm{dph}$ fish $(15 \mathrm{ml}$ Falcon tubes), $500 \mu \mathrm{l}$ PBS was then added, and for the $533 \mathrm{dph}$ fish (50 ml Falcon tubes), 4,500 $\mu \mathrm{l}$ PBS was added. An $80 \mu \mathrm{l}$ sample was placed on a slide and a $60 \times 24-\mathrm{mm}$ coverslip was placed over the top (exact volume to fill coverslip with no air pockets). MRCs were quantified for size $\left(\mu \mathrm{m}^{2}\right)$ and abundance on an LSC (Compucyte, Cambridge, Massachusetts) coupled with a $20 \times$ objective (UPlanFL/20x/0.50/ $\infty / 0.17$, Olympus, Melville, NY, USA) in combination with a LSC argon laser (488 nm) following Lima and Kültz (2004). The equation used to determine MRC abundance was:

$$
\begin{aligned}
& {\left[\left(V_{\text {sample }} / V_{\text {slide }}\right) \cdot\left(\mathrm{CS}_{\text {area }} / S_{\text {area }}\right)(\# \text { cells }) \cdot(8 / \# \text { arches })\right] /} \\
& \quad F_{\text {mass }}=\# \mathrm{MRC} / \mathrm{g}
\end{aligned}
$$

where $V_{\text {sample }}=$ final volume of resuspended sample $(\mu \mathrm{l})$, $V_{\text {slide }}=$ volume of slide $=80 \mu \mathrm{l}, \mathrm{CS}_{\text {area }}=$ cover slip area $=1,440 \mathrm{~mm}^{2}, \quad S_{\text {area }}=$ LSC scan area $=2 \mathrm{~mm} \times$ $5 \mathrm{~mm}=10 \mathrm{~mm}^{2}$, \# cells $=\#$ cells determined by LSC, \# arches $=\#$ gill arches pooled in sample, $F_{\text {mass }}=$ mass of fish $(\mathrm{g})$.
Tissue homogenate $\mathrm{Na}^{+}, \mathrm{K}^{+}$-ATPase activities

Tissue samples ( $n=8-9 /$ salinity) were thawed, placed on ice, $100 \mu \mathrm{l}$ of SEI buffer containing $0.5 \%$ sodium deoxycholate was added (final concentration $0.1 \%$ ), and tissue was immediately homogenized (Tissuemiser, Fisher Scientific) for 20-30 s sample ${ }^{-1}$ and centrifuged for $1 \mathrm{~min}$ at $5,000 \mathrm{~g}$ to remove large solids. Supernatant was collected and split into two, 0.6-ml siliconized vials, one for protein measurement, and one for $\mathrm{Na}^{+}, \mathrm{K}^{+}$-ATPase measurement, the latter of which was immediately frozen at $-80^{\circ} \mathrm{C}$ until the results of the protein assays were obtained.

Protein concentration was determined in duplicate according to the bicinchoninic acid method by Smith et al. (1985) in a microplate reader (SPECTRAFluor Plus, Tecan, Research Triangle Park, North Carolina, USA).

$\mathrm{Na}^{+}, \mathrm{K}^{+}$-ATPase activity levels were determined in duplicate by the kinetic conversion of nicotinamide adenine dinucleotide (NADH) to $\mathrm{NAD}^{+}$in homogenates, and read at $340 \mathrm{~nm}$ from $2-10 \mathrm{~min}$ in a microplate reader. Methods were modified from those of Penefsky and Bruist (1984) and McCormick (1993) and optimized for green sturgeon, for a final reaction volume in each microwell with $10 \mu \mathrm{L}$ of sample and $200 \mu \mathrm{L}$ of reaction mixture that contained $142 \mathrm{mM} \mathrm{NaCl}, 31.5 \mathrm{mM} \mathrm{KCl}, 7.9 \mathrm{mM} \mathrm{MgCl}_{2}$, $1 \mathrm{U} \mathrm{ml}^{-1}$ lactate dehydrogenase $(\mathrm{LDH}), \quad 1.25 \mathrm{U} \mathrm{ml}^{-1}$ pyruvate kinase (PK), $2.0 \mathrm{mM}$ phosphoenolpyruvate (PEP), $1.0 \mathrm{mM}$ adenosine triphosphatase (ATP), $1.0 \mathrm{mM}$ $\mathrm{NADH}$, and $50 \mathrm{mM}$ imidazole in the presence or absence of $0.5 \mathrm{mM}$ ouabain at $\mathrm{pH} 7.5$ and $25^{\circ} \mathrm{C}$. Specific activities are expressed both as international units (IU) $\mathrm{g}^{-1}$ protein according to Penefsky and Bruist (1984) and as $\mu$ mol ADP mg protein ${ }^{-1} \mathrm{~h}^{-1}$ according to McCormick (1993) and McKenzie et al. (1999).

\section{Gastro-intestinal tract sampling}

Methods were based on Wilson et al. (1996) and Kerstetter and White (1994). In Experiment 2, after at least 6 weeks ( 43-48 days) at their acclimation salinity, fish were starved for 3 days to clear the gastro-intestinal tract (GIT) of any food, overdosed in anesthetic (500 $\mathrm{mg}^{-1} \mathrm{MS}-222$; at their acclimation salinity), and then quickly sampled for blood (caudal sinus), and a small cannula tube (PE50, Clay Adams) attached to a syringe was inserted into the rectum to sample fluid at the terminus of the GIT. Fish were placed in a supine position and a ventral mid-line incision was made to expose the GIT. Suture silk (4-0) was used to isolate three regions of the GIT: (1) the stomach (behind the insertion of the swim bladder to the pyloric sphincter), (2) the anterior-middle intestine (pyloric sphincter to the inception of the spiral intestine), and (3) the spiral intestine 
(the inception of the spiral intestine to the rectum). After isolating the three regions, fluid and solid samples were collected by making a small incision at one end of a section, and then gently squeezing the section into an open $1.5-\mathrm{ml}$ microcentrifuge tube. The samples were immediately placed on ice, and then centrifuged at 13,000 rpm for $5 \mathrm{~min}$. The fluid was decanted into a separate vial, and the mass of the fluid and solid were determined using tared collection vials. Fluids and solids were stored on ice prior to analyses for $\mathrm{pH}$ and base $\left(\mathrm{HCO}_{3}{ }^{-}\right.$and $\left.\mathrm{CO}_{3}{ }^{2-}\right)$, and stored at $-80^{\circ} \mathrm{C}$ until analyses for ions.

\section{GIT fluid and solid analyses}

GIT fluid $\mathrm{pH}$ was measured using a microelectrode on an acumet pH meter. A double titration method (Hills 1973; Wilson et al. 1996) was used to determine the amount of base in the samples. For fluids, $50 \mu \mathrm{l}$ was added to $10 \mathrm{ml}$ of $40 \mathrm{mM} \mathrm{NaCl}$ in a $30-\mathrm{ml}$ glass beaker. The beaker was supplied with a steady, gentle bubbling of nitrogen, and continuously mixed with a magnetic stir bar. The initial $\mathrm{pH}$ was measured, and then $20 \mathrm{mM} \mathrm{HCl}$ was gradually added by pipet (and recorded) to reduce the $\mathrm{pH}$ to below 4 to remove all $\mathrm{HCO}_{3}{ }^{-}$and $\mathrm{CO}_{3}{ }^{2-}$ as gaseous $\mathrm{CO}_{2}$. The solution was then gradually titrated back to the starting $\mathrm{pH}$ using $20 \mathrm{mM}$ $\mathrm{NaOH}$. The differential in number of moles of $\mathrm{HCl}$ and $\mathrm{NaOH}$ required to return to the starting $\mathrm{pH}$ is then equivalent to the number of moles of $\mathrm{HCO}_{3}{ }^{-}$equivalents in the original sample. For the mucus tube solids (Shehadeh and Gordon 1969), a similar procedure was followed, except the mass of the mucus tube added was determined, $1 \mathrm{M} \mathrm{HCl}$ was needed to dissolve the mucus tubes, and $0.2 \mathrm{M} \mathrm{NaOH}$ was used to bring the solution back to the original $\mathrm{pH}$.

Fluid samples and blood plasma were analyzed by flame photometry (IL 343, Instrument Laboratory, Inc., Lexington, MA, USA) for determination of $\mathrm{Na}^{+}$and $\mathrm{K}^{+}$concentrations, and a chloride titrator (CMT10, Radiometer America, Cleveland, OH, USA) for determination of $\mathrm{Cl}^{-}$concentrations. $\mathrm{Mg}^{2+}$ and $\mathrm{Ca}^{2+}$ concentrations for both fluids and mucus tube solids were determined by inductively coupled plasma-atomic emission spectrometry.

\section{Statistical analysis}

One-way ANOVAs followed by Tukey's pair-wise comparison tests were used to compare whole-tissue-homogenate $\mathrm{Na}^{+}, \mathrm{K}^{+}$-ATPase activities for different salinity treatments for gill, kidney, pyloric caeca, and spiral intestine separately (SAS Institute, NC, USA; JMPIN 4.0.4 academic version 2001).

Within a salinity treatment, one-way ANOVAs were used to compare ion concentrations for either fluid or solid between ambient water, GIT regions, and blood plasma. A
Kruskal-Wallis non-parametric test followed by Dunn's pair-wise comparison was used for data that did not meet ANOVA assumptions of normality and homogeneity of variance. Student's $t$ tests were used to compare fluid and solid individual ion concentrations within a GIT region.

For cell dissociation data, two-way ANOVAs were used to compare factors of initial age and salinity for MRC size and MRC abundance relative to body mass (Experiment 2 data replaced Experiment 1100 dph data).

For IHC gill data, the relationship between $\mathrm{Na}^{+}, \mathrm{K}^{+}$ATPase content (relative fluorescence in the LSC integral) and MRC area was analyzed using linear regression. The number of MRCs $\mathrm{mm}^{-1}$ for different gill regions were analyzed by a one-way ANOVA. The number of MRCs $\mathrm{mm}^{-1}$ was analyzed by two-way ANOVA comparing factors of initial age and salinity. Relationships between gill dimensions of interlamellar distance and lamellar length to fish total length were analyzed by linear and nonlinear regression, respectively.

In the GIT, within a salinity, total magnesium, calcium or base were compared between different regions by oneway ANOVAs. For the SW treatment, student's $t$ tests were used to compare fluid and solid individual ion concentrations within a GIT region.

For two-way ANOVAs, if the interaction between age and salinity was found to be significant, individual treatment groups were compared. If the interaction was not found to be significant, the main effects of age and salinity were analyzed. Tukey's pair-wise comparison tests were used only if the overall ANOVA was found to be significant. Data were $\log _{10}$ transformed to meet ANOVA assumptions when necessary. In all cases, differences were considered significant at $P<0.05$. With the exception of the regression equations, all statistical values are reported as mean \pm SEM.

\section{Results}

\section{Gill MRC localization}

Gill MRCs were located based on staining for $\mathrm{Na}^{+}, \mathrm{K}^{+}-$ ATPase (Fig. 1). The number of MRCs $\mathrm{mm}^{-1}$ was highest at the base of lamellae (determined to be the first $50 \mu \mathrm{m}$ of the lamella from the filament, which was wider than the lamellar region further from the filament), intermediate on gill filaments, and lowest on gill lamellae (Fig. 2a). For MRC number, there were significant salinity and age effects for filament and lamellar MRCs, but the salinity $\times$ age interaction was not significant in either case. In filaments, MRC number increased with salinity (FW < SW, BW not different from either; Fig. 2b) and age $(100<170$ and 533 dph; Fig. 2c). In lamellae, MRC 
Fig. 1 Gill mitochondria-rich cell (MRC) locations in 533 days-post-hatch juvenile green sturgeon, Acipenser medirostris acclimated to freshwater $(<3 \mathrm{ppt}$; a), brackish water (10 ppt; b) or seawater (33 ppt; c) for 7 weeks. $\mathrm{Na}^{+}$, $\mathrm{K}^{+}$-ATPase staining is in green, cell nuclei are stained red. Bar represents $50 \mu \mathrm{m} . F$ filament, $B L$ base of lamellae, $L$ lamellae. MRCs were located on both lamellae and filaments in freshwater, and primarily on the filament in brackish water and seawater
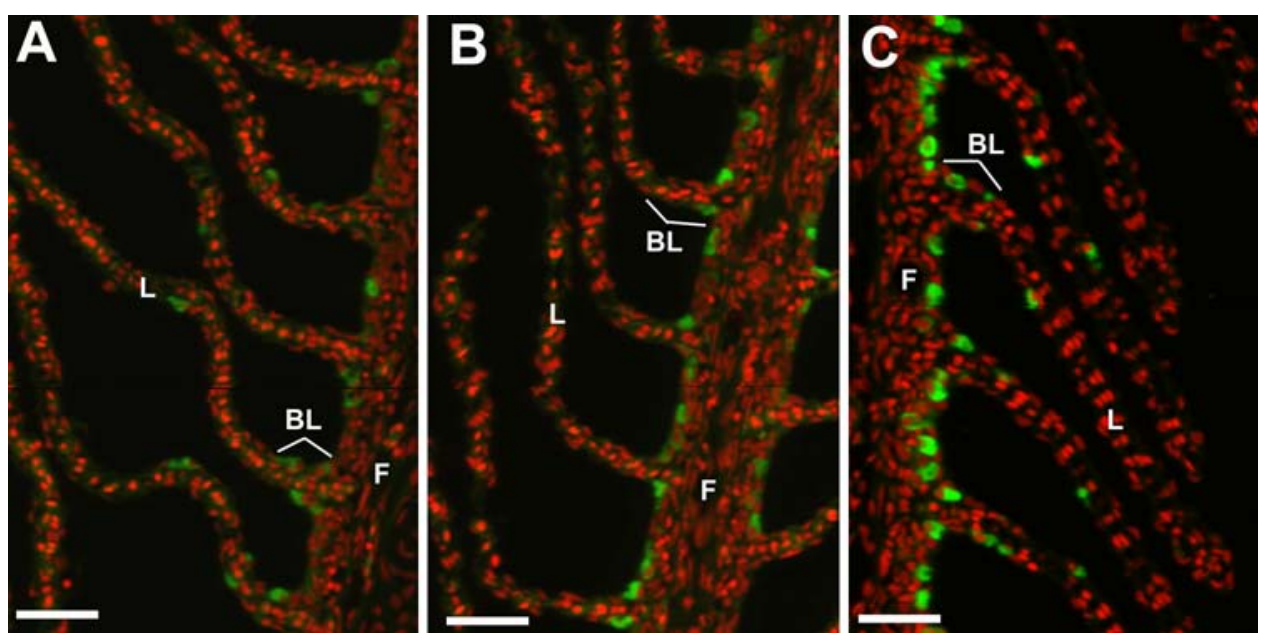

number decreased with salinity $(\mathrm{FW}<\mathrm{BW}$ and $\mathrm{SW}$; Fig. 2b) but did not change with age (Fig. 2c). At the base of lamellae, MRC number did not change with salinity (Fig. 2b) or age (Fig. 2c).

\section{Gill MRC size and abundance}

For MRC size, there were significant salinity and age effects, but the salinity $\times$ age interaction was not significant. MRC area increased with exposure to saline water (FW < BW, SW not different from either; Fig. 3a) and age $(100<170$ and 533 dph; Fig. 3b).

$\mathrm{Na}^{+}, \mathrm{K}^{+}$-ATPase content was directly related to MRC area (Fig. 3c) by the equation: $\mathrm{Na}^{+}, \mathrm{K}^{+}$-ATPase content $=70647 \times$ MRC area $-611273 \quad\left(r^{2}=0.904\right.$, $N=92$ ).

MRC abundance relative to body mass decreased with age/fish size, and was also related to salinity in the $170 \mathrm{dph}$ fish. In the $170 \mathrm{dph}$ fish, the BW group had fewer MRCs than the FW and SW groups, and was similar to fish at 533 dph (Fig. 4).

\section{Gill changes with fish size}

For morphometric changes in the gills, relationships with salinity were not significant, therefore salinity treatments were pooled and gill metrics were compared with fish total length (TL). Gill interlamellar distance was directly related to fish size, according to the equation: interlamellar distance $(\mu \mathrm{m})=37.874+0.0266 \times \mathrm{TL}(\mathrm{mm}), r^{2}=0.62, N=45$ (Fig. 5a). Gill lamellar length increased rapidly with fish size up to about 300-mm, and then increased more slowly thereafter (Fig. 5b). The relationship is described by the equation: lamellae length $(\mu \mathrm{m})=-384.09+626.03$ $\left(1-\exp (-0.007 \times\right.$ Fish TL $(\mathrm{mm})), r^{2}=0.65, N=45$.
Tissue homogenate $\mathrm{Na}^{+}, \mathrm{K}^{+}$-ATPase activities

In the gills, BW and SW groups had greater $\mathrm{Na}^{+}, \mathrm{K}^{+}$ATPase activities than the FW group (Table 1). Thus, gill $\mathrm{Na}^{+}, \mathrm{K}^{+}$-ATPase activity was related to salinity in contrast to $\mathrm{Na}^{+}, \mathrm{K}^{+}$-ATPase content that was related to MRC area (Fig. 3c). In the kidney, the FW group had greater $\mathrm{Na}^{+}$, $\mathrm{K}^{+}$-ATPase activities than $\mathrm{BW}$ or $\mathrm{SW}$ groups. In the pyloric caeca, the $\mathrm{SW}$ group had $\mathrm{Na}^{+}, \mathrm{K}^{+}$-ATPase activities four times greater than FW or BW. For spiral intestine $\mathrm{Na}^{+}, \mathrm{K}^{+}$-ATPase activities, there were no differences between salinities.

\section{Kidney $\mathrm{Na}^{+}, \mathrm{K}^{+}$-ATPase localization}

Kidney proximal and distal tubule segments were identified by $\mathrm{Na}^{+}, \mathrm{K}^{+}$-ATPase staining differences, because proximal tubule segments show basolateral-localized staining, and distal tubules and collecting ducts show staining throughout the cytoplasm (Lin et al. 2004; Nebel et al. 2005; Uchida et al. 1996; Fig. 6). Distal tubule segments were stained from the inner lumen to the outer wall of the tubule, and included distal tubules and collecting ducts. In all salinities, the distal tubule segments were smaller and more densely stained by $\mathrm{Na}^{+}, \mathrm{K}^{+}$-ATPase than were the proximal tubule segments, as would be expected for $\mathrm{Na}^{+}$, $\mathrm{Cl}^{-}$and water reabsorption (in SW). Interestingly, staining was the most intense in distal tubule segments in BW. In proximal tubule segments, staining was localized to the outer walls, and there were noticeable differences between salinities. In FW, the tubule walls were thin and the lumen was often collapsed (Fig. 6a). In BW, the tubule walls were slightly thicker and the lumen was occasionally dilated (Fig. 6b). In SW, the tubule walls were very thick and the lumen appeared to be fully dilated (Fig. 6c). 

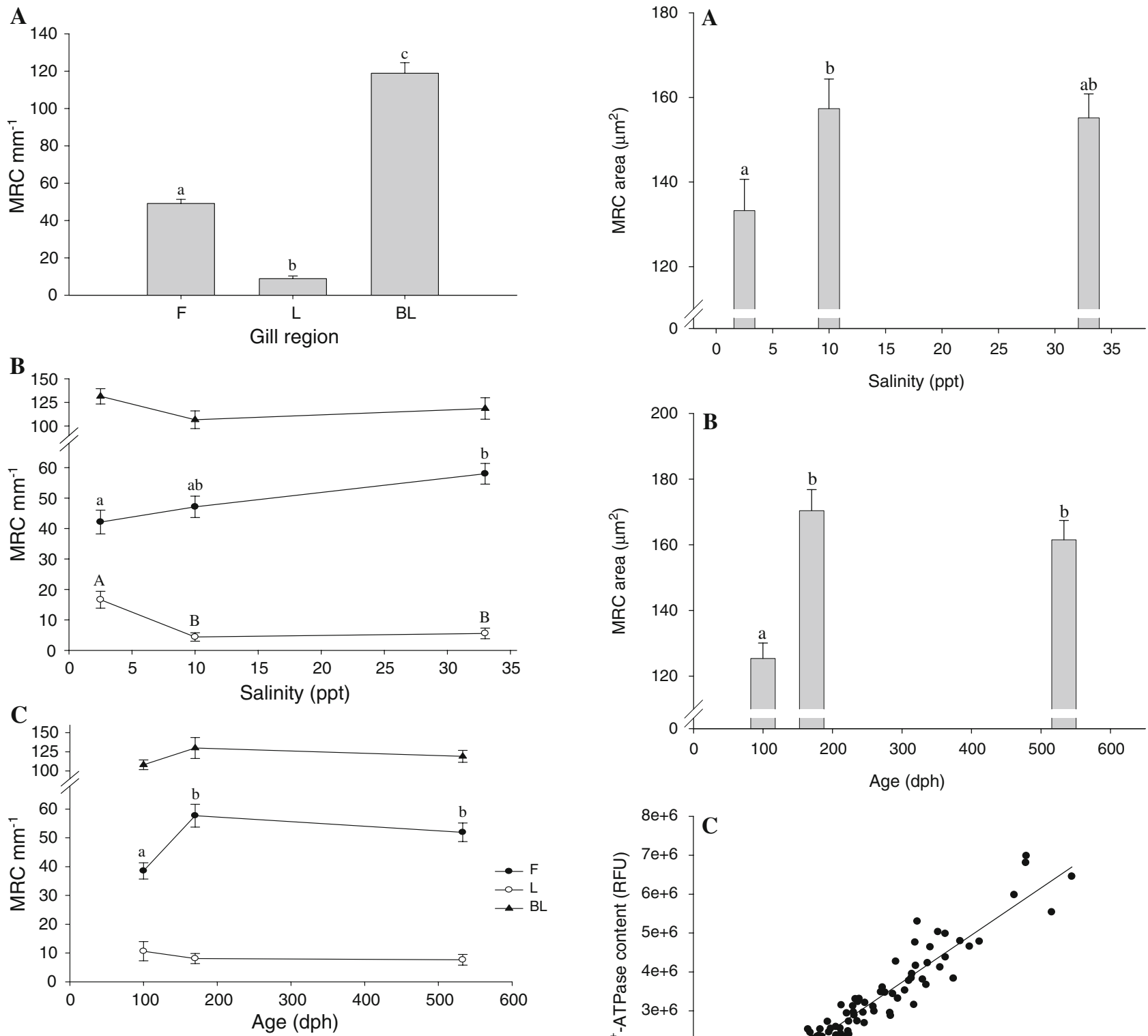

Fig. 2 Mean (+SEM) gill mitochondria rich cells per $\mathrm{mm}$ in a gill region, $\mathbf{b}$ with salinity, and $\mathbf{c}$ with age (days post hatch). $F$ filament, $B L$ base of lamellae, $L$ lamellae. In a $n=15$ for each gill region, in b $n=15$ for each salinity, and in $\mathbf{c} n=16$ for $100 \mathrm{dph}, 15$ for 170 $\mathrm{dph}$, and 14 for $533 \mathrm{dph}$. Different letters indicate significant differences between treatment groups, one-way ANOVA, Tukey's pair-wise comparison

Ion and base concentrations in GIT fluids and solids

Fish acclimated to $<3$ ppt had almost no measurable fluid or solids in their GITs. In fish acclimated to $10 \mathrm{ppt}$, fluids were mainly present in the anterior-middle intestine, and very little if any mucus tube solids were present. In the fluids, $\mathrm{Na}^{+}$did not change between the ambient water and the stomach, but increased in the intestine, where it was at similar concentrations to the plasma (Table 2). $\mathrm{Cl}^{-}$was at similar concentrations in the ambient water, stomach and
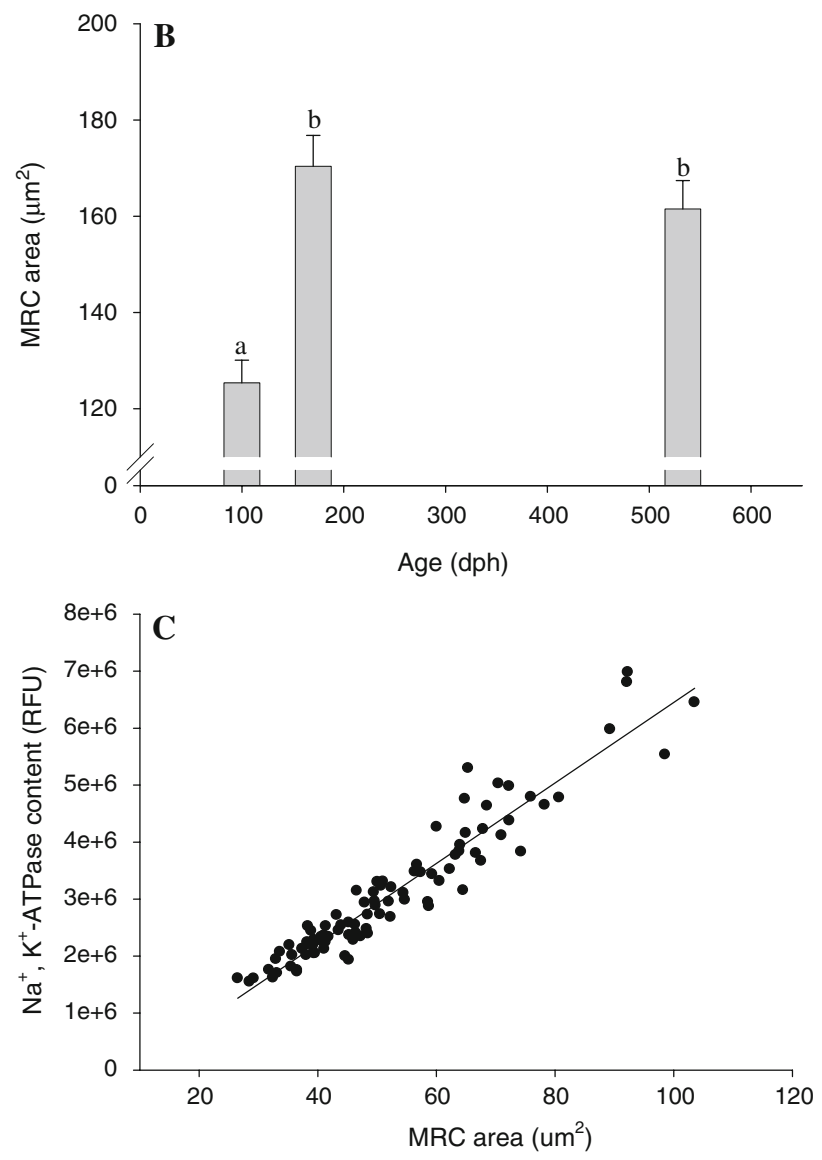

Fig. 3 Juvenile green sturgeon, Acipenser medirostris, mean (+SEM) individual mitochondria-rich cell (MRC) areas among a salinities $(<3,10$, and $33 \mathrm{ppt})$ and $\mathbf{b}$ ages $(100,170$, and 533 days post hatch), and $\mathbf{c} \mathrm{Na}^{+}, \mathrm{K}^{+}$-ATPase content relative to MRC area. For $\mathbf{a}$ and $\mathbf{b}, \mathrm{MRC}$ area was determined by cell dissociation, and different letters represent significant differences between groups (2-way ANOVA, $N=6-9, P<0.05)$. For c $\mathrm{Na}^{+}, \mathrm{K}^{+}$-ATPase content was determined by immunohistochemistry, and is equivalent to the number of relative fluorescent units (RFU) per contouring integral, which were optimized to detect individual MRCs by laser scanning cytometry. The relationship is: $\mathrm{Na}^{+}, \mathrm{K}^{+}$-ATPase content $=$ $70647 \times$ MRC area $-611273, r^{2}=0.904, n=92$. MRCs have a smaller area than when revealed via cell-dissociation techniques, because they are partially occluded by other cells when attached to the gills and viewed as a cross section 


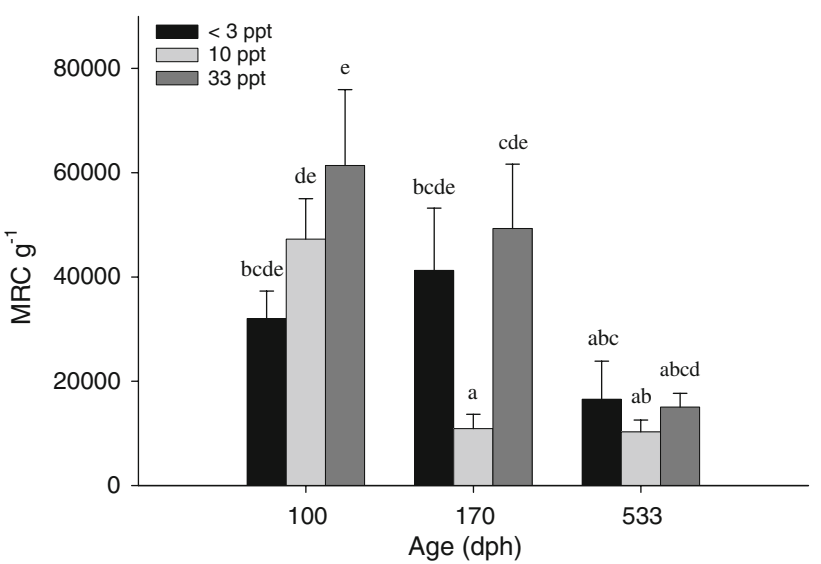

Fig. 4 Mean (+SEM) mitochondria-rich cell number relative to wet body mass, determined by cell dissociation in juvenile green sturgeon, Acipenser medirostris. Different letters represent significant differences between groups (2-way ANOVA, $N=6-9, P<0.05$ )
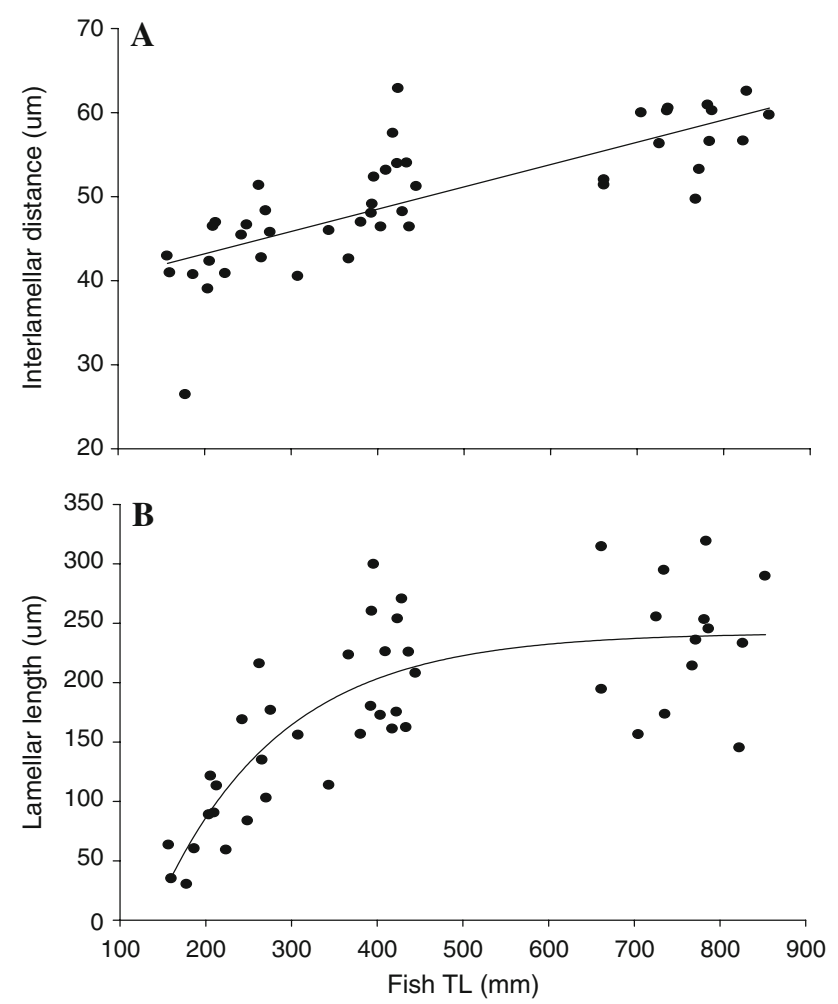

Fig. 5 Changes in gill a filament interlamellar distance (ID) and b lamellar length with fish total length (TL). In a the linear relationship is described by the equation: mean ID $(\mu \mathrm{m})=37.874+0.0266 \times$ $\mathrm{TL}(\mathrm{mm}), \quad r^{2}=0.62, n=45$. In $\mathbf{b}$, the curvilinear relationship is described by the equation: Lamellae TL (um) $=-384.09+$ $626.03\left(1-\exp (-0.007 \times\right.$ Fish TL $(\mathrm{mm})), r^{2}=0.65, n=45$

plasma, but decreased in the intestine. $\mathrm{K}^{+}$was at similar concentrations in the ambient water and the plasma, but was approximately five times higher in the stomach and intestine. Because many of the fish acclimated to $10 \mathrm{ppt}$
Table 1 Tissue-homogenate $\mathrm{Na}^{+}, \mathrm{K}^{+}$-ATPase activities for $100 \mathrm{dph}$ juvenile green sturgeon after 7 weeks of acclimation to $<3$, 10, or 33 ppt water (Experiment 2)

\begin{tabular}{lcc}
\hline FW $(<3 \mathrm{ppt})$ & BW $(10 \mathrm{ppt})$ & $\mathrm{SW}(33 \mathrm{ppt})$ \\
\hline Gills & & \\
$8.39 \pm 0.99^{\mathrm{a}}$ & $23.78 \pm 3.80^{\mathrm{b}}$ & $15.55 \pm 2.76^{\mathrm{b}}$ \\
$(8.83 \pm 1.04)$ & $(25.02 \pm 4.00)$ & $(16.36 \pm 2.91)$ \\
Kidney & & \\
$115.45 \pm 10.81^{\mathrm{a}}$ & $87.61 \pm 6.36^{\mathrm{b}}$ & $74.87 \pm 9.12^{\mathrm{b}}$ \\
$(121.44 \pm 11.37)$ & $(92.16 \pm 6.69)$ & $(78.76 \pm 9.60)$ \\
Pyloric caeca & & \\
$26.63 \pm 2.57^{\mathrm{a}}$ & $23.42 \pm 4.42^{\mathrm{a}}$ & $100.94 \pm 10.13^{\mathrm{b}}$ \\
$(28.02 \pm 2.70)$ & $(24.64 \pm 4.65)$ & $(106.18 \pm 10.66)$ \\
Spiral intestine & & \\
$30.14 \pm 3.60$ & $31.50 \pm 3.63$ & $36.44 \pm 3.16$ \\
$(31.71 \pm 3.78)$ & $(33.14 \pm 3.82)$ & $(38.33 \pm 3.33)$ \\
\hline
\end{tabular}

Values are mean \pm SEM, and are IU $\mathrm{g}^{-1}$ protein, except for values in parentheses which are $\mu \mathrm{mol}$ ADP mg protein ${ }^{-1} \mathrm{~h}^{-1}(N=8$ except for gills where $N=9$ ). Data were analyzed by one-way ANOVA, Tukey's pair-wise comparison, different superscript letters indicate significant differences $(P<0.05)$ between salinity-acclimation groups

had very low GIT fluid volumes, there were insufficient samples to analyze either $\mathrm{Mg}^{2+}$ or $\mathrm{Ca}^{2+}$ concentrations statistically. Fluid $\mathrm{pH}$ dropped significantly in the stomach, but then regained levels similar to ambient water by the anterior-middle intestine.

In fish acclimated to $33 \mathrm{ppt}$, the GIT was consistently inflated with fluid and the intestines also contained mucus tube solids. In the fluids, $\mathrm{Na}^{+}$decreased by $>50 \%$ between ambient water and the stomach, presumably in the esophagus. $\mathrm{Na}^{+}$decreased again by almost $75 \%$ between the stomach and anterior-middle intestine, and again by almost $50 \%$ between the anterior-middle intestine and the spiral intestine. $\mathrm{Cl}^{-}$showed similar patterns. $\mathrm{K}^{+}$fluctuated somewhat within the GIT, and was only different between the stomach and the spiral intestine, where it was significantly lower. $\mathrm{Mg}^{2+}$ did not increase between ambient water and the stomach, but did increase greatly between and stomach and anterior-middle intestine and again between the anterior-middle intestine and spiral intestine. $\mathrm{Ca}^{2+}$ did not change between ambient water and the GIT fluids. Mucus tube solids were present in the anterior to spiral intestine and had high concentrations of $\mathrm{Mg}^{2+}$ and $\mathrm{Ca}^{2+}$. For $\mathrm{Mg}^{2+}$, the concentrations were approximately 2-3 times greater in the solids than in the fluids (solids and fluids compared by the assumption that $1 \mathrm{~g}$ is equivalent to $1 \mathrm{ml}$ ). However, the total amount of $\mathrm{Mg}^{2+}$ was greater in the fluids (Fig. 7a). For $\mathrm{Ca}^{2+}$, the concentrations were approximately $50-180$ times greater in the solids than in the fluids. In contrast to $\mathrm{Mg}^{2+}$, the total amount of $\mathrm{Ca}^{2+}$ 

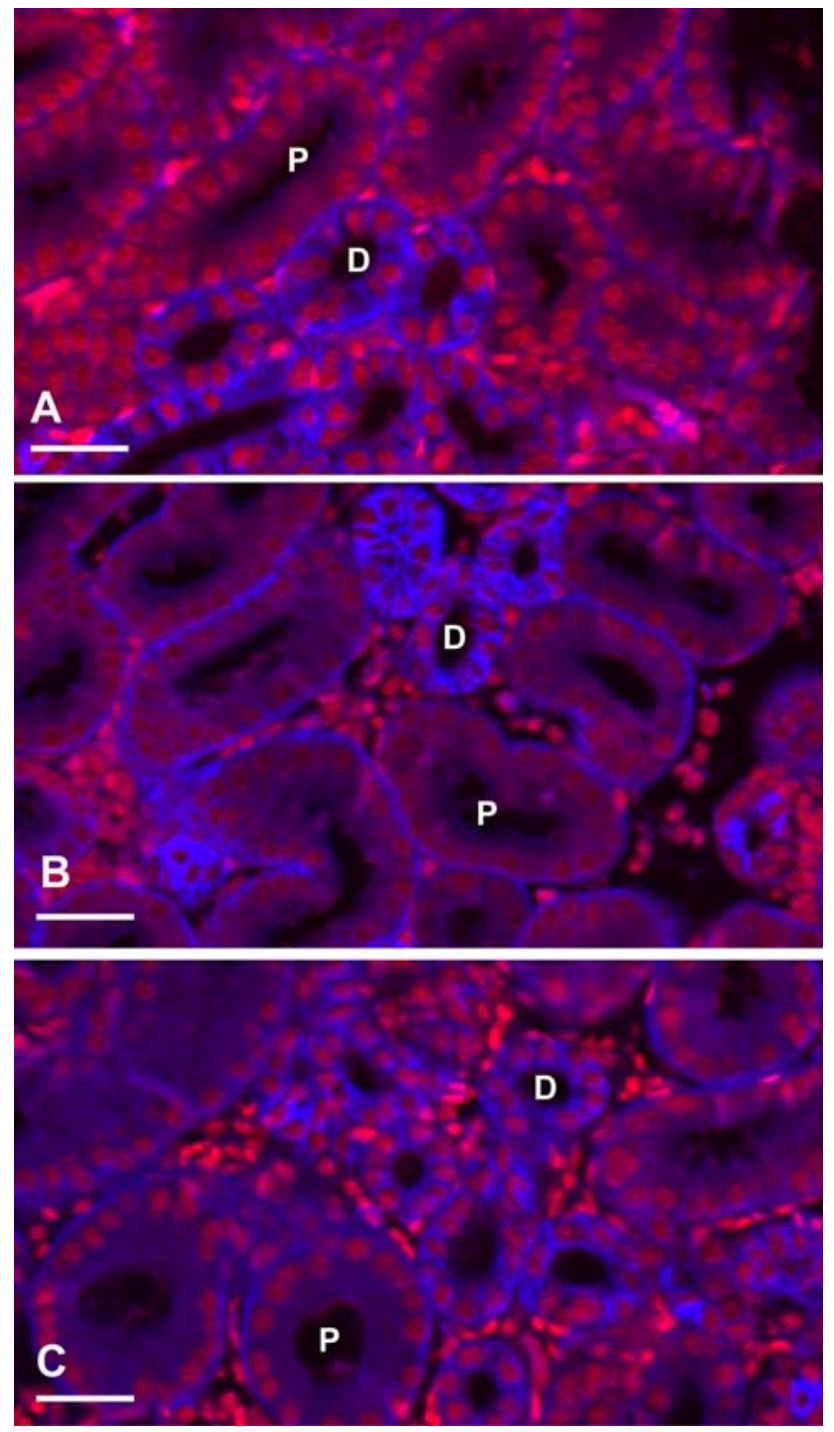

Fig. 6 Kidney $\mathrm{Na}^{+}, \mathrm{K}^{+}$-ATPase staining locations in juvenile green sturgeon, Acipenser medirostris acclimated to freshwater ( $<3 \mathrm{ppt} ; \mathbf{a})$, brackish water $\left(10 \mathrm{ppt}\right.$; b) or seawater $\left(33 \mathrm{ppt}\right.$ c) for 7 weeks. $\mathrm{Na}^{+}$, $\mathrm{K}^{+}$-ATPase staining is in blue, cell nuclei are stained red, lumen regions are unstained. Bar represents $10 \mu \mathrm{m}$. In all salinities, the distal tubule segments ( $D$ distal tubules and collecting ducts) were smaller and more intensely stained (throughout cells) than proximal tubule segments $(\mathrm{P})$. In the proximal tubule segments, staining was localized to the basal cell surfaces, and cell thickness and lumen diameter increased with salinity

was greater in the solids than the fluids (Fig. 7b). The total amount of base $\left(\mathrm{HCO}_{3}{ }^{-}\right.$and $2 \mathrm{CO}_{3}{ }^{2-}$ ) was very low in $\mathrm{BW}$ (Fig. 7c). However, in SW, total base increased in the fluids between the stomach and the anterior-middle intestine, but did not change between the anterior-middle intestine and the spiral intestine. In SW mucus tube solids, total base was similar to fluids in the anterior-middle intestine, but increased significantly between the anteriormiddle intestine and spiral intestine, indicating that base was continuing to be excreted or precipitated into the mucus tube solids. The total milliequivalents of base in the solids was very similar to the total milliequivalents of $\mathrm{Ca}^{2+}$. In contrast to fish acclimated to BW, in SW acclimated fish, fluid $\mathrm{pH}$ remained comparable to ambient water into the stomach, but then increased through each region of the GIT.

Interestingly, in the Experiment 2 fish (Table 2), concentrations of plasma $\mathrm{Na}^{+}, \mathrm{K}^{+}$, and $\mathrm{Cl}^{-}$were similar between fish acclimated to 10ppt and 33ppt in contrast to similar sized and aged fish from Experiment 1 (Allen and Cech 2007). The acclimation was slightly different in Experiment 2, where fish were acclimated to $10 \mathrm{ppt}$ for 3 weeks prior to additional increases in salinity up to $33 \mathrm{ppt}$, possibly stimulating hyperosmotic regulatory mechanisms (Altinok et al. 1998).

\section{Discussion}

The process of SW acclimation has been primarily examined in terms of salinity-based changes in the more derived groups of anadromous or euryhaline fishes (Evans et al. 2005). Relatively little is known about the mechanisms of SW adaptation in primitive anadromous fishes (Wright 2007). The primitive green sturgeon undergoes physiological adjustments to SW in the gills, kidney, and GIT. Our data suggest that many of the changes are induced by exposure to either isosmotic or hyperosmotic salinities. Body size appears to be a primary factor in successful acclimation to hyperosmotic conditions, although some age-related changes occur during a relatively discrete developmental period, indicating that endogenous mediation (i.e., endocrine regulation) likely also plays a role.

\section{Gill changes}

Juvenile green sturgeon are able to acclimate to isosmotic or hyperosmotic salinities in a large part due to salinityinduced and age/size-based developmental changes in the gills, the primary ionoregulatory site in most teleost species (Evans et al. 2005). When exposed to elevated salinities, the size of MRCs increased (in BW but not SW), and the number of MRCs increased on the filaments and decreased on the lamellae. MRC sizes have been shown to typically increase with salinity in many anadromous species (McCormick 1995; Zydlewski and McCormick 2001) including sturgeons (Altinok et al. 1998; Carmona et al. 2004). Ion excretory cells have been reported as being larger than ion uptake cells (Foskett et al. 1981), although differences may be species-specific. Thus, the larger MRCs in $\mathrm{BW}$ as compared to FW were expected, but the indistinguishable SW MRC sizes from either of the other groups were surprising. The localization changes of MRCs in the 


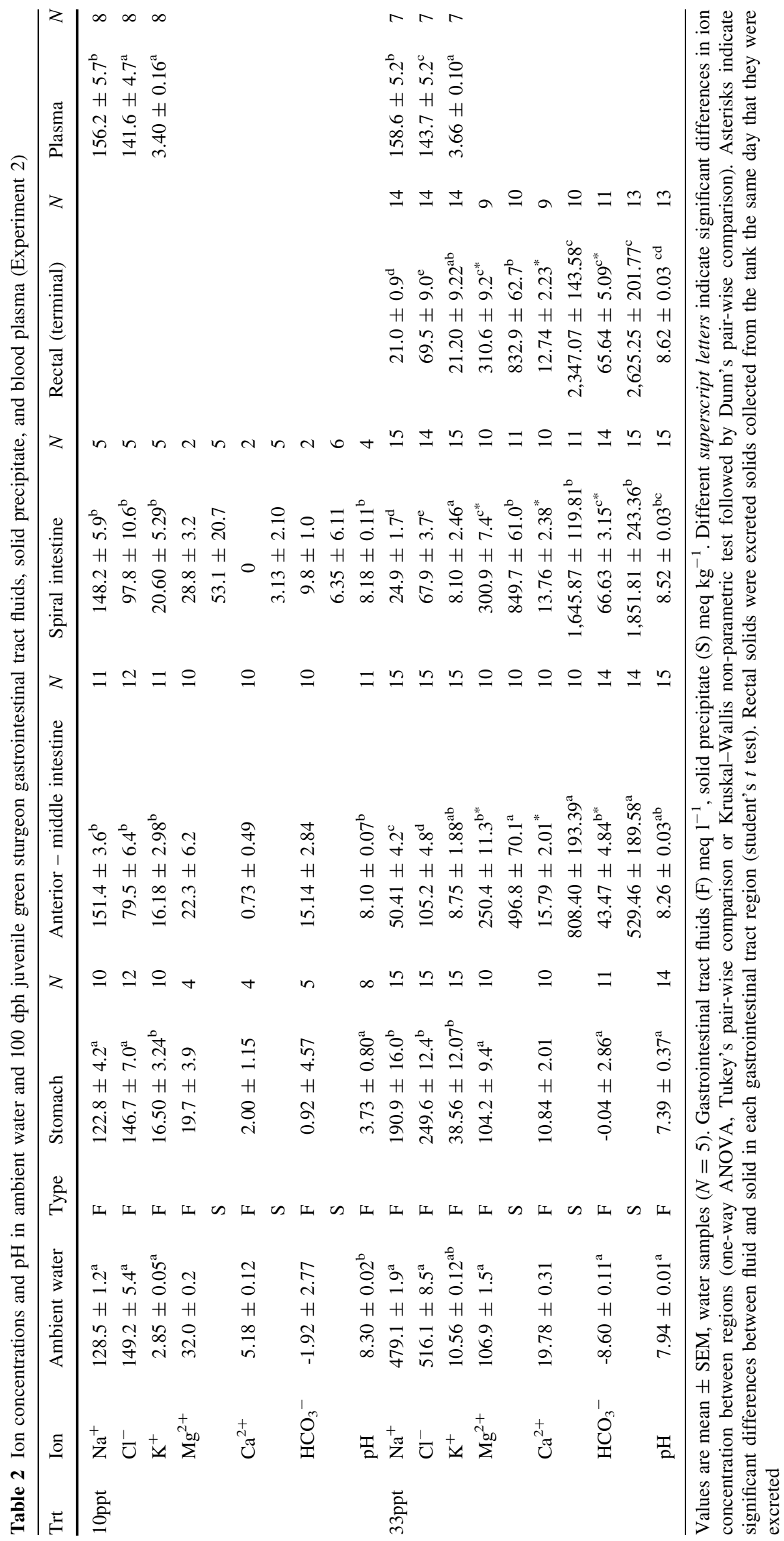



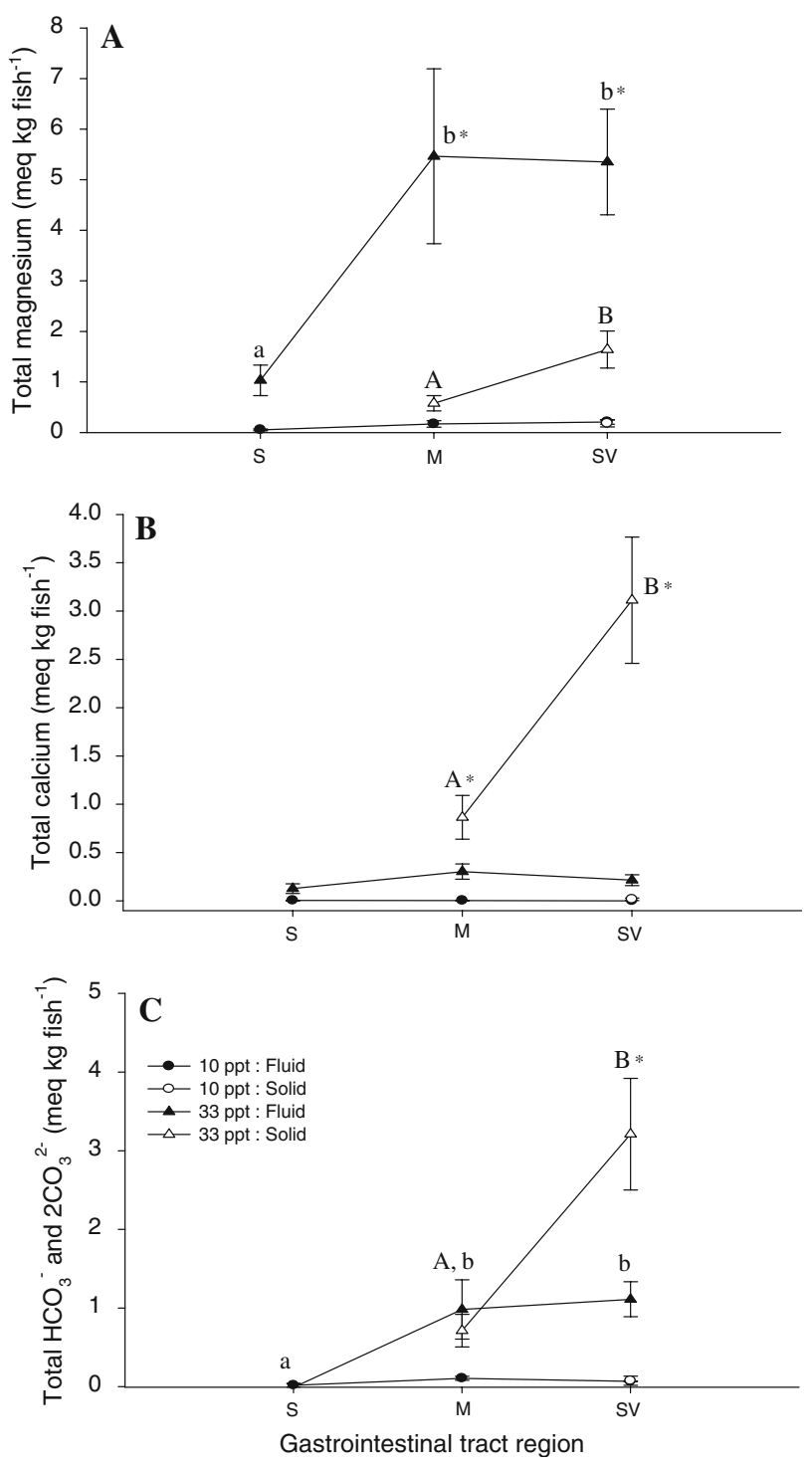

Fig. 7 Mean $( \pm$ SEM) a total magnesium, $\mathbf{b}$ total calcium, and $\mathbf{c}$ total $\mathrm{HCO}_{3}{ }^{-}$and $2 \mathrm{CO}_{3}{ }^{2-}$ in meq kg fish ${ }^{-1}$ in gastrointestinal tract (GIT) fluids and solids of $100 \mathrm{dph}$ juvenile green sturgeon, Acipenser medirostris, acclimated for 7 weeks (starved for the final $72 \mathrm{~h}$ ) to either brackish water (10 ppt) or seawater (33 ppt; Experiment 2). GIT fluid volumes were very low in brackish water fish, and as a result, there were not enough samples to analyze statistically. Seawater fish GIT fluids or solids were analyzed by separate one-way ANOVAs followed by Tukey's means comparison test. Different letters indicate significant differences between GIT regions. Asterisks indicate significant differences between fluid and solid in each GIT region (student's $t$ test). $S$ stomach, $M$ middle-intestine, $S V$ spiral valve intestine

gills were similar to that observed in other anadromous species in response to salinity. MRCs in both locations are often present in hyposmotic environments, whereas in hyperosmotic environments, lamellar MRCs are often not present, presumably because active ion uptake is not as necessary, although ion uptake can also occur from cells located on the filament as well (Laurent et al. 2006). MRCs at the base of lamellae have been shown to remain constant in number despite changes in salinity (Uchida and Kaneko 1996; Varsamos et al. 2002). Smaller MRCs have been found on the lamellae, and larger MRCs on the primary filaments in anadromous salmonids (Mizuno et al. 2000; Pisam et al. 1988; Uchida et al. 1996) and shad (Zydlewski and McCormick 2001). Similar to other anadromous species, studies on sturgeon species have generally shown increasing numbers of MRCs in hyperosmotic environments (Altinok et al. 1998; Carmona et al. 2004), but with a decrease in lamellar MRC numbers (Cataldi et al. 1995; McKenzie et al. 1999).

In green sturgeon, relative MRC abundance generally decreased with increasing body mass, although in fish acclimated to BW salinities, MRC abundance decreased at an earlier age than those in FW or SW. This is likely due to an effect of decreased gill surface area for ion and water diffusion in comparison to a larger internal fluid volume as fish size increases. Evans (1969) found that gill surface area is related to body mass (in grams) to the power of 0.88 , indicating that with an increase in magnitude of size, surface area is reduced by $25 \%$, and relative water flux decreases similarly. Similarly, in white sturgeon A. transmontanus, the closest congener to green sturgeon, Burggren et al. (1979) found a declining relationship between gill surface area and body mass $\left(\mathrm{SA}_{\text {gill }}=1.235\right.$ body weight $^{-0.158}$ ) and noted that this mass specific-surface area was comparatively low to teleosts. Thus, with increasing fish body mass, the decreasing gill surface area to body volume ratio suggests that less MRCs are needed to maintain osmotic homeostasis. External salinity changes are likely to be felt at the fastest rate when fish are small, and the slowest rate when fish are larger, thus reducing the need for as many MRCs on the gill surface in proportion to body mass. The lower number of MRCs in the BW $170 \mathrm{dph}$ group may indicate an energetic savings in these fishes at this age due to lower requirements for ion transport in an isosmotic environment. Correspondingly, fish near this age have been found in estuarine environments (Nakamoto et al. 1995) and appear to experience salinity greater than freshwater (Allen et al. 2009). However, ionoregulatory costs have been found to be low in teleosts (Morgan and Iwama 1998), and whole-body energetic costs assessed through oxygen consumption measurements were not different between salinities or ages in green sturgeon (Allen and Cech 2007). Ion regulatory adjustments may be represented more clearly on the enzymatic and cellular level in terms of $\mathrm{Na}^{+}, \mathrm{K}^{+}$-ATPase and MRC changes, as well as other transporters.

In juvenile green sturgeon, MRC $\mathrm{Na}^{+}, \mathrm{K}^{+}$-ATPase content, which is comparable to the number of pumps or pumping capacity because the antibody used binds to $\mathrm{Na}^{+}$, 
$\mathrm{K}^{+}$-ATPase pumps but does not determine enzymatic activity, was related to MRC size and not salinity. Thus, there would appear to be a greater potential for hypoosmotic regulation with increasing age, when MRCs are larger and have a greater ion pumping capacity. In contrast, gill $\mathrm{Na}^{+}, \mathrm{K}^{+}$-ATPase activity (i.e., ion pumping activity) increased with salinity. Interestingly, Sardella and Kültz (2008) found that MRC content was related to salinity in juvenile green sturgeon. The contrasting findings are likely due to a much longer acclimation time in this study ( 7 vs. 2 weeks) and different salinities examined. The relationship of $\mathrm{Na}^{+}, \mathrm{K}^{+}$-ATPase content to MRC size, to our knowledge, has received very little study to date. In contrast, $\mathrm{Na}^{+}, \mathrm{K}^{+}$-ATPase activity has been well studied and shown to increase with hyperosmotic salinity in a number of fishes (McCormick 1995), including anadromous salmonids (Hoar 1988), shad (Zydlewski and McCormick 1997), lampreys (Beamish et al. 1978) and several sturgeon species (Martinez-Alvarez et al. 2005; McKenzie et al. 1999; Rodriguez et al. 2002). The relationship between ion pumping capacity and activity is likely complex, as tissue $\mathrm{Na}^{+}, \mathrm{K}^{+}$-ATPase activity is a sum of the activity of several isoforms, which are known to vary with salinity (Richards et al. 2003), species (Bystriansky et al. 2006) and tissue type (Cutler et al. 2000). In this study, the $\mathrm{Na}^{+}, \mathrm{K}^{+}$ATPase antibody used likely detected a number of different isoforms, although knowledge of $\mathrm{Na}^{+}, \mathrm{K}^{+}$-ATPase isoforms in sturgeons is lacking.

Similar to the gill surface area to internal volume effect noted above, the gill infrastructure changes in proportion to fish size. Interlamellar distance (the distance between lamellae along the gill filaments) increases at a constant rate with fish size. In contrast, in white sturgeon, the number of lamellae was found to be directly proportional to filament length regardless of fish size (Burggren et al. 1979), indicating that interlamellar distance is constant. Differences from this study are likely to be species specific as Burggren et al. (1979) noted that white sturgeon had 8-12 lamellae $\mathrm{mm}^{-1}$ whereas for green sturgeon, there were 17-25 lamellae $\mathrm{mm}^{-1}$ (based on data in Fig. 5a). In green sturgeon, lamellar length increased with fish size, with a rapid increase between 15 and $45 \mathrm{~cm}$ (3-6 months), when fish have been documented in estuarine habitats in the wild (Nakamoto et al. 1995). As noted above, MRC size also increases rapidly over the same time period, as does MRC number in the gill filaments. Therefore, it would appear that there is a great deal of developmental growth, and an ontogenetic change in the gills between 3 to 6 months post hatch, that may be necessary before most fish can acclimate to SW salinities. This change may be similar to pre-adaptive SW preparatory changes typically associated with salmonid smoltification (Hoar 1988).
Kidney changes

In hyposmotic environments, teleosts experience the passive influx of water and ion loss, which is counteracted in part in the kidney by increased internal ion reabsorption and the production of large volumes of dilute urine (Marshall and Grosell 2006). In green sturgeon, the increase in kidney $\mathrm{Na}^{+}, \mathrm{K}^{+}$-ATPase in FW as compared to BW or SW suggests a similar regulatory strategy. In smolting salmonids, prior to SW entry, kidney $\mathrm{Na}^{+}, \mathrm{K}^{+}$-ATPase activities may increase (McCartney 1976) although this increase may be species-specific (Ewing and Rodgers 1998). After SW transfer, several studies have found that kidney $\mathrm{Na}^{+}, \mathrm{K}^{+}$ATPase activity may not change (Fuentes et al. 1997; Madsen et al. 1995), although other euryhaline species have shown greater activities in FW (Lin et al. 2004). In other sturgeon species, kidney $\mathrm{Na}^{+}, \mathrm{K}^{+}$-ATPase activity declines with hyperosmotic salinity in species that normally experience these salinities as a part of their life history (Krayushkina et al. 2006).

In the kidneys, the smaller, distal tubule segments of green sturgeon were more intensely stained for $\mathrm{Na}^{+}, \mathrm{K}^{+}$ATPase in FW and BW than SW. This result would be expected for the greater ion uptake needs in $\mathrm{FW}$, although $\mathrm{Na}^{+}, \mathrm{Cl}^{-}$and water would also be expected to be reabsorbed in SW to counteract passive water losses (Marshall and Grosell 2006). The high $\mathrm{Na}^{+}, \mathrm{K}^{+}$-ATPase content of the distal tubule segments in $\mathrm{BW}$ is interesting, especially because overall kidney tissue homogenates had a lower activity than those from FW fish. Because GIT fluid volumes were low in BW fish and ambient salinity is higher, fish at this salinity are likely balancing low drinking rates with reduced ion resorption needs. The thicker epithelial cells in proximal tubule segments in SW may be due to increased $\mathrm{Mg}^{2+}$ and $\mathrm{Ca}^{2+}$ secretion or as an adaptation for limiting ion uptake by separating blood and extracellular fluids a maximum distance from the kidney filtrate. The dilated lumen would increase this effect, minimizing the surface area contact of the filtrate with the sides of the lumen. In sturgeons, kidney adaptations to hyperosmotic environments have included reduced glomerular size, reduced number of glomeruli, reduced glomerular vascularization, decreased proximal tubule diameter, increased distal tubule diameter, and decreased distal tubule epithelial cell thickness (Cataldi et al. 1995; Krayushkina et al. 1996). These changes presumably lead to a decreased filtration rate in SW, although this was not verified in these studies. Interestingly, studies of sturgeon renal corpuscle morphology suggest a low glomerular filtration rate even in FW, due to the structures of the capillary wall, the glomerular basement membrane, and the podocytes, which form the filtration barrier (Ojeda et al. 2003). 


\section{GIT changes}

The function of the GIT in green sturgeon can be assessed from an anterior to posterior direction, following the path of water. In teleosts, the current model for intestinal function in iono- and osmoregulation (reviewed by Grosell 2006) involves increased drinking rates in hyperosmotic conditions to counteract dehydration by osmotic water loss. As water is ingested, it is desalinated in the esophagus by the passive and active removal of $\mathrm{Na}^{+}$and $\mathrm{Cl}^{-}$(Hirano and Mayer-Gostan 1976; Loretz 1995; Parmelee and Renfro 1983), although the esophagus has low permeability to water and other ions (Parmelee and Renfro 1983). This results in a reduced osmolality of the water (Hirano and Mayer-Gostan 1976; Nagashima and Ando 1994) facilitating its absorption in the intestine (Wilson et al. 2002). In green sturgeon acclimated to $\mathrm{SW}$, the decrease in $\mathrm{Na}^{+}$and $\mathrm{Cl}^{-}$concentrations (by approximately 50\%) in the esophagus (based on the difference between these ion concentrations in SW and in stomach fluid) is consistent with this teleost model. Ultrastructure studies on sturgeon esophageal surface cells have concluded that they are involved in osmotic resorptive activities (Radaelli et al. 2000).

Water then moves into the anterior intestine, which is the primary region for water uptake (Kerstetter and White 1994; Wilson et al. 1996). The process for water absorption depends on $\mathrm{Cl}^{-} / \mathrm{HCO}_{3}{ }^{-}$exchange (Grosell et al. 2005). $\mathrm{HCO}_{3}{ }^{-}$produced by endogenous respiration within the enterocyte (Grosell et al. 2007; Wilson et al. 1996) or arising from transfer across the basolateral membrane (Ando 1990; Grosell et al. 2005) is exchanged for luminal $\mathrm{Cl}^{-}$(Grosell et al. 2001; Kurita et al. 2008; Wilson et al. 2002). Water osmotically follows $\mathrm{Cl}^{-}$, apparently by a transcellular route (Sundell et al. 2003), and although water absorption can occur throughout the intestine, it is generally greatest in the anterior intestine due to the high concentration of $\mathrm{Cl}^{-}$(Grosell 2006). Similarly, in green sturgeon, the anterior intestine, and in particular, the pyloric caeca appears to be the primary GIT region for water uptake. In $\mathrm{SW}, \mathrm{Cl}^{-}$and $\mathrm{Na}^{+}$concentrations had the largest decrease in the anterior-middle intestine, and $\mathrm{HCO}_{3}{ }^{-}$increased greatly. Further, the fourfold increase in $\mathrm{Na}^{+}, \mathrm{K}^{+}$-ATPase activity in $\mathrm{SW}$ in the pyloric caeca contrasted with the lack of change in activity in the spiral intestine. Because $\mathrm{Na}^{+}, \mathrm{K}^{+}$-ATPase drives water absorption and $\mathrm{Cl}^{-} / \mathrm{HCO}_{3}{ }^{-}$exchange (Grosell 2006; Loretz 1995), the increase in activity indicates the degree of water absorption occurring. In support, $\mathrm{Na}^{+}, \mathrm{K}^{+}$-ATPase activity did not increase in the pyloric caeca in BW (iso-osmotic), because dehydration would not be a factor (Allen and Cech 2007) and associated drinking would be minimal. The cellular structure of the pyloric caeca is similar to that of the anterior intestine in teleosts (Buddington and Diamond
1987) and sturgeons (Buddington and Doroshov 1986), and therefore, it represents a large increase in intestinal surface area. The increases in pyloric caeca $\mathrm{Na}^{+}, \mathrm{K}^{+}$-ATPase activity in hyperosmotic salinities have also been found in teleosts (Nielsen et al. 1999; Seidelin et al. 2000; Veillette and Young 2004), where it has been shown to have a major role in water absorption (Boge et al. 1988; Veillette et al. 2005; Wilson et al. 1996). However, the activities and magnitude of increase are not nearly as great as that seen in green sturgeon.

In hyperosmotic environments, the posterior intestine is also a site of fluid absorption in teleosts (Veillette et al. 1993, 1995). Accordingly, anadromous salmonids have shown increases in intestinal $\mathrm{Na}^{+}, \mathrm{K}^{+}$-ATPase activities either during the parr-smolt transformation (Usher et al. 1991), or after exposure to SW (Fuentes et al. 1997), and have shown increases in fluid transport rate (Veillette et al. 1993). However, similar to green sturgeon, spiral intestine $\mathrm{Na}^{+}, \mathrm{K}^{+}$-ATPase activities in other species of sturgeon did not increase with salinity (Jarvis and Ballantyne 2003; Rodriguez et al. 2002) or only increased transiently (He et al. 2008). The spiral intestine of sturgeon does not appear to structurally change between FW and SW (Cataldi et al. 1995) and may be more involved in nutrient uptake (Gawlicka et al. 1995). Although in some teleost species, intestinal water uptake in hyperosmotic conditions may be more closely linked to diet-related nutrient and salt uptake than drinking rate (Scott et al. 2008).

In fishes studied to date, $\mathrm{Cl}^{-}$uptake along the intestinal tract is higher than $\mathrm{Na}^{+}$, and has been demonstrated to be the primary driving force for water uptake (Grosell 2006). Interestingly, in the green sturgeon, $\mathrm{Cl}^{-}$uptake is similar or only slightly greater than $\mathrm{Na}^{+}$uptake in the anteriormiddle intestine $\left(\mathrm{Cl}^{-}: 144 \mathrm{meq} \mathrm{l}^{-1} ; \mathrm{Na}^{+}: 140 \mathrm{meq}{ }^{-1}\right)$ and spiral intestine $\left(\mathrm{Cl}^{-}: 37 \mathrm{meq} \mathrm{l}^{-1} ; \mathrm{Na}^{+}: 26 \mathrm{meq} \mathrm{l}^{-1}\right)$, although the significance of this is not known. Concentrations of $\mathrm{K}^{+}$in the GIT fluctuated greatly in SW with an increasing trend in rectal fluid, somewhat similar to that observed in teleosts (Marshall and Grosell 2006). In contrast, in $\mathrm{BW}, \mathrm{Na}^{+}$and $\mathrm{K}^{+}$actually increased between the stomach and anterior-middle intestine (presumably due to changes at the pyloric caeca) to match or exceed plasma concentrations, while $\mathrm{Cl}^{-}$decreased. The differences between regulation of these ions in the iso-osmotic BW conditions is likely due to differences in drinking rate and water absorption, which were further indicated by very low intestinal fluid volumes (with the exception of the anteriormiddle intestine region) and low amounts of $\mathrm{HCO}_{3}{ }^{-}$base. It is possible that $\mathrm{Na}^{+}$was balancing the minor amount of base secreted in $\mathrm{BW}$, which did not increase intestinal $\mathrm{pH}$ beyond that of the ambient water.

In green sturgeon acclimated to $\mathrm{SW}$, high intestinal base $\left(\mathrm{HCO}_{3}{ }^{-}\right.$and $\left.2 \mathrm{CO}_{3}{ }^{2-}\right)$ concentrations led to a high $\mathrm{pH}$ 
(up to 8.6), and precipitated $\mathrm{Ca}^{2+}$ out of the fluids, similar to intestinal regulation in teleosts. In teleosts, this precipitation of $\mathrm{CaCO}_{3}$ and concentration of $\mathrm{Mg}^{2+}$ and $\mathrm{SO}_{4}{ }^{2-}$ in the fluids is due to the low permeability of the intestine for these ions (Wilson et al. 2002). In green sturgeon, base and $\mathrm{Ca}^{2+}$ concentrations were nearly the same in the solids, indicating that these two appear to precipitate out together, as has been shown in teleosts (Shehadeh and Gordon 1969; Walsh et al. 1991), which reduces intestinal fluid osmolality and facilitates greater water absorption (Wilson et al. 2002). In contrast, base concentrations in the fluids were much less than $\mathrm{Mg}^{2+}$ concentrations, which likely were balanced by $\mathrm{SO}_{4}{ }^{2-}$, although this was not measured. In green sturgeon, the peak in fluid base of 66 meq $1^{-1}$ was very similar to that observed in gulf toadfish (Opsanus beta; Walsh et al. 1991) and fed rainbow trout (Wilson et al. 1996), but considerably less than the $100 \mathrm{mM}$ concentrations achieved in the posterior GIT of some teleosts (Marshall and Grosell 2006), including starved rainbow trout (Wilson et al. 1996). Of interest, the base concentration of intestinal precipitate was much greater than that observed in other anadromous fishes, with similar concentrations only found in the marine teleost, butterfish (Centronotus gunnellus; Wilson 1999). This resulted in higher total base concentrations in the solid precipitates than the fluids, which is very unlike other fishes studied to date, where solid precipitates account for about $18 \%$ of total base (Wilson 1999). Furthermore, it would appear that this system of osmoregulation and anion-exchange in the GIT is widespread in sturgeons, as a study in the comparatively FW Siberian sturgeon, A. baerii, noted declining $\mathrm{Cl}^{-}$concentrations, increasing $\mathrm{HCO}_{3}{ }^{-}$concentrations and intestinal precipitates when fish were acclimated to slightly hyperosmotic salinities (Taylor and Grosell 2006).

\section{Conclusions}

The mechanisms of osmo- and ionoregulation utilized by green sturgeon in terms of gill, kidney, and GIT changes between hyposmotic and hyperosmotic environments, show a great deal of similarity to more derived anadromous and euryhaline fishes. In green sturgeon, body size and salinity exposure appear to play key roles in achieving ionic homeostasis in hyperosmotic conditions. However, based on the rapid changes in gill MRC sizes over a discrete age interval, it would appear that endogenous factors likely play a role in SW adaptation as well. Notable differences in aspects of osmo- and ionoregulation between green sturgeon and more derived fishes do occur in aspects of intestinal base excretion. These include the importance of the pyloric caeca in water uptake and base exchange, the apparent limited use of the spiral intestine in osmoregulation, and the greater proportion of base precipitating in the intestinal solids than remaining in fluids. Further investigations of the cellular mechanisms involved in osmoregulation, particularly in the gastrointestinal tract and the endocrine regulation of osmo- and ionoregulation merit further research. The relative conservation of the gill, kidney, and GIT mechanisms for ionic homeostasis across these fish taxa provides evidence for their functional importance.

Acknowledgments We thank the Yurok Tribal Council and the Yurok Fisheries Program for broodstock fish; S. Doroshov, J. Van Eenennaam, and J. Linares-Casenave for providing larval fish from the broodstock; P. Lutes, E. Hallen, K. Menard, J. Newman, B. Myers, M. Paulson, K. Brown, and W. Newman for facility assistance and recommendations; T. Allen, J. Zamora, N. Ponferrada, R. Kaufman, T. Matsumoto, K. Jasperson, D. Hickey, A. Vlazny, A. Oye and B. Jang for technical assistance and insight; and S. Doroshov, and P. Moyle for helpful comments on the manuscript. Financial assistance was provided by the California Bay-Delta Authority (grants ERP-02D-P57 and SP2006-1035), the Anadromous Fish Restoration Program (US Fish and Wildlife Service, US Bureau of Reclamation; grant no. 11332-1-G005), the University of California Agricultural Experiment Station (grant no. 3455-H to JJC), the NSF (grant no. 0244569 to DK), the UC Davis Ecology Graduate Group (Block Grant and Jastro-Shields Scholarship to PJA), the BML (travel grant to PJA), Emily Schwalen Memorial Prize, the Marin Rod and Gun Club, the Granite Bay Flycasters, and the California Federation of FlyFishers (scholarships to PJA).

Open Access This article is distributed under the terms of the Creative Commons Attribution Noncommercial License which permits any noncommercial use, distribution, and reproduction in any medium, provided the original author(s) and source are credited.

\section{References}

Allen PJ (2005) Seawater adaptation in juvenile green sturgeon, Acipenser medirostris. Dissertation, University of California, Davis, p 187

Allen PJ, Cech JJ Jr (2007) Age/size effects on juvenile green sturgeon, Acipenser medirostris, oxygen consumption, growth, and osmoregulation in saline environments. Environ Biol Fish 79:211-229

Allen PJ, Hobbs JA, Cech JJ Jr, Van Eenennaam JP, Doroshov SI (2009) Using trace elements in pectoral fin rays to assess life history movements in sturgeon: estimating age at initial seawater entry in Klamath River green sturgeon. Trans Am Fish Soc 138:240-250

Altinok I, Galli SM, Chapman FA (1998) Ionic and osmotic regulation capabilities of juvenile Gulf of Mexico sturgeon, Acipenser oxyrinchus desotoi. Comp Biochem Physiol A 120:609-616

Ando M (1990) Effects of bicarbonate on salt and water transport across the intestine of the seawater eel. J Exp Biol 150:367-379

Beamish FWH, Strachan PD, Thomas E (1978) Osmotic and ionic performance of the anadromous sea lamprey Petromyzonmarinus. Comp Biochem Physiol A 60:435-444

Boeuf G (1993) Salmonid smolting: a pre-adaptation to the oceanic environment. In: Rankin JC, Jensen FB (eds) Fish ecophysiology. Chapman \& Hall, London, pp 105-135 
Boge G, Lopez L, Peres G (1988) An in vivo study of the role of the pyloric caeca in water absorption in rainbow trout (Salmo gairneri). Comp Biochem Physiol A 91:9-13

Buddington RK, Diamond J (1987) Pyloric ceca in fish: a "new" absorptive organ. Am J Physiol 252:G65-G76

Buddington RK, Doroshov SI (1986) Structural and functional relations of the white sturgeon alimentary canal (Acipenser transmontanus). J Morphol 190:201-213

Burggren W, Dunn J, Barnard K (1979) Branchial circulation and gill morphometrics in the sturgeon Acipenser transmontanus, an ancient Chondrosteian fish. Can J Zool 57:2160-2170

Bystriansky JS, Richards JG, Schulte PM, Ballantyne JS (2006) Reciprocal expression of gill $\mathrm{Na}^{+} / \mathrm{K}^{+}$-ATPase alpha-subunit isoforms $\alpha 1 \mathrm{a}$ and $\alpha 1 \mathrm{~b}$ during seawater acclimation of three salmonid fishes that vary in their salinity tolerance. J Exp Biol 209:1848-1858

Carmona R, Garcia-Gallego M, Sanz A, Domenzain A, Ostos-Garrido MV (2004) Chloride cells and pavement cells in gill epithelia of Acipenser naccarii: ultrastructural modifications in seawateracclimated specimens. J Fish Biol 64:553-566

Cataldi E, Ciccotti E, Di Marco P, Di Santo O, Bronzi P, Cataudella S (1995) Acclimation trials of juvenile Italian sturgeon to different salinities: morpho-physiological descriptors. J Fish Biol 47:609_ 618

Cutler CP, Brezillon S, Bekir S, Sanders IL, Hazon N, Cramb G (2000) Expression of a duplicate $\mathrm{Na}, \mathrm{K}$-ATPase $\beta_{1}$-isoform in the European eel (Anguilla anguilla). Am J Physiol 279:R222R229

Evans DH (1969) Studies on the permeability to water of selected marine, freshwater and euryhaline teleosts. J Exp Biol 50:689-703

Evans DH, Piermarini P, Choe KP (2005) The multifunctional fish gill: dominant site of gas exchange, osmoregulation, acid-base regulation, and excretion of nitrogenous waste. Physiol Rev 85:97-177

Ewing RD, Rodgers JD (1998) Changes in physiological indices of smolting during seaward migration of wild coho salmon, Oncorhynchus kisutch. Aquaculture 168:69-83

Folmar LC, Dickhoff WW (1980) The parr-smolt transformation (smoltification) and seawater adaptation in salmonids: a review of selected literature. Aquaculture 21:1-38

Foskett JK, Logsdon CD, Turner T, Machen TE, Bern HA (1981) Differentiation of the chloride extrusion mechanism during seawater adaptation of a teleost fish, the cichlid Sarotherodon mossambicus. J Exp Biol 93:209-224

Fuentes J, Soengas JL, Rey P, Rebolledo E (1997) Progressive transfer to seawater enhances intestinal and branchial $\mathrm{Na}^{+}-\mathrm{K}^{+}$. ATPase activity in non-anadromous rainbow trout. Aquac Int 5:217-227

Gawlicka A, Teh SJ, Hung SSO, Hinton DE, de la Noue J (1995) Histological and histochemical changes in the digestive tract of white sturgeon larvae during ontogeny. Fish Physiol Biochem 14:357-371

Grande L, Bemis WE (1991) Osteology and phylogenetic relationships of fossil and recent paddlefishes (Polyodontidae) with comments on the interrelationships of Acipenseriformes. J Vert Paleo 11(Suppl. 1):1-121

Grosell M (2006) Intestinal anion exchange in marine fish osmoregulation. J Exp Biol 209:2813-2827

Grosell M, Laliberte CN, Wood S, Jensen FB, Wood CM (2001) Intestinal $\mathrm{HCO}_{3}{ }^{-}$secretion in marine teleost fish: evidence for an apical rather than a basolateral $\mathrm{Cl}^{-} / \mathrm{HCO}_{3}{ }^{-}$exchanger. Fish Physiol Biochem 24:81-95

Grosell M, Wood CM, Wilson RW, Bury NR, Hogstrand C, Rankin C, Jensen FB (2005) Bicarbonate secretion plays a role in chloride and water absorption of the European flounder intestine. Am J Physiol 288:R936-R946
Grosell M, Gilmour KM, Perry SF (2007) Intestinal carbonic anhydrase, bicarbonate, and proton carriers play a role in the acclimation of rainbow trout to seawater. Am J Physiol 293:R2099-R2111

He X, Zhuang P, Zhang L, Xie C (2008) Osmoregulation in juvenile Chinese sturgeon (Acipenser sinensis Gray) during brackish water adaptation. Fish Physiol Biochem. doi:10.1007/ s10695-008-9230-5

Hills AG (1973) Acid-base balance: chemistry; physiology, pathophysiology. Williams and Wilkins, Baltimore

Hirano T, Mayer-Gostan N (1976) Eel esophagus as an osmoregulatory organ. Proc Natl Acad Sci 73:1348-1350

Hoar WS (1988) The physiology of smolting salmonids. In: Hoar WS, Randall DJ (eds) Fish Physiology, v.11. Academic Press, Inc., San Diego, pp 275-343

Hwang PP, Lee TH (2007) New insights into fish ion regulation and mitochondrion-rich cells. Comp Biochem Physiol A 148:479497

Jarvis PL, Ballantyne JS (2003) Metabolic responses to salinity acclimation in juvenile shortnose sturgeon Acipenser brevirostrum. Aquaculture 219:891-909

Kerstetter TH, White RJ (1994) Changes in intestinal water absorption in coho salmon during short-term seawater adaptation: a developmental study. Aquaculture 121:171-180

Keys AB, Willmer EM (1932) Chloride-secreting cells in the gills of fishes, with special reference to the common eel. J Physiol 76:368-378

Krayushkina LS, Panov AA, Gerasimov AA, Potts WTW (1996) Changes in sodium, calcium and magnesium ion concentrations in sturgeon (Huso huso) urine and in kidney morphology. J Comp Physiol B 165:527-533

Krayushkina LS, Semenova OG, Vyushina AV (2006) Level of serum cortisol and $\mathrm{Na}^{+} / \mathrm{K}^{+}$ATP-ase activity of gills and kidneys in different acipenserids. J Appl Ichthyol 22(Suppl. 1):182-187

Kültz D, Somero GN (1995) Osmotic and thermal effects of in situ ATPase activity in permeabilized gill epithelial cells of the fish Gillichthys mirabilis. J Exp Biol 198:1883-1894

Kurita Y, Nakada T, Kato A, Doi H, Mistry AC, Chang MH, Romero MF, Hirose S (2008) Identification of intestinal bicarbonate transporters involved in formation of carbonate precipitates to stimulate water absorption in marine teleost fish. Am J Physiol 294:R1402-R1412

Kynard B, Parker E, Parker T (2005) Behavior of early life intervals of Klamath River green sturgeon, Acipenser medirostris, with a note on body color. Environ Biol Fish 72:85-97

Laurent P, Chevalier C, Wood CM (2006) Appearance of cuboidal cells in relation to salinity in gills of Fundulus heteroclitus, a species exhibiting branchial $\mathrm{Na}^{+}$but not $\mathrm{Cl}^{-}$uptake in freshwater. Cell Tissue Res 325:481-492

Lee TH, Hwang PP, Lin HC, Huang FL (1996) Mitochondria-rich cells in the branchial epithelium of the teleosts, Oreochromis mossambicus, acclimated to various hypotonic environments. Fish Physiol Biochem 15:513-523

Lima RN, Kültz D (2004) Laser scanning cytometry and tissue microarray analysis of salinity effects on killifish chloride cells. J Exp Biol 207:1729-1739

Lin CH, Tsai RS, Lee TH (2004) Expression and distribution of Na, K-ATPase in gill and kidney of the spotted green pufferfish, Tetraodon nigroviridis, in response to salinity challenge. Comp Biochem Physiol A 138:287-295

Loretz CA (1995) Electrophysiology of ion transport in teleost intestinal cells. In: Wood CM, Shuttleworth TJ (eds) Cellular and molecular approaches to fish ionic regulation. Academic Press, San Diego, pp 25-56

Madsen SS, Jensen MK, Nohr J, Kristiansen K (1995) Expression of $\mathrm{Na}^{+}-\mathrm{K}^{+}$-ATPase in the brown trout, Salmo trutta: in vivo 
modulation by hormones and seawater. Am J Physiol 269:R1339-R1345

Marshall WS, Grosell M (2006) Ion transport, osmoregulation, and acid-base balance. In: Evans DH, Claiborne JB (eds) The physiology of fishes, 3rd edn edn. CRC Press, Boca Raton, pp 177-230

Martinez-Alvarez RM, Sanz A, Garcia-Gallego M, Domezain A, Domezain J, Carmona R, del Valle Ostos-Garrido M, Morales AE (2005) Adaptive branchial mechanisms in the sturgeon Acipenser naccarii during acclimation to saltwater. Comp Biochem Physiol A 141:183-190

McCartney TH (1976) Sodium potassium dependent ATPase activity in gills and kidneys of Atlantic salmon Salmo-salar. Comp Biochem Physiol A 53:351-353

McCormick SD (1993) Methods for nonlethal gill biopsy and measurement of $\mathrm{Na}^{+}, \mathrm{K}^{+}$-ATPase activity. Can J Fish Aquat Sci 50:656-658

McCormick SD (1995) Hormonal control of gill $\mathrm{Na}^{+}, \mathrm{K}^{+}$-ATPase and chloride cell function. In: Wood CM, Shuttleworth TJ (eds) Fish Physiology v.14: cellular and molecular approaches to fish ionic regulation. Academic Press, San Diego, pp 285-315

McCormick SD, Shrimpton JM, Zydlewski JD (1997) Temperature effects on osmoregulatory physiology of juvenile anadromous fish. In: Wood CM, McDonald DG (eds) Society for Experimental Biology Seminar Series; Global warming: implications for freshwater and marine fish. Cambridge University Press, New York, pp 279-301

McDowall RM (1988) Diadromy in fishes. Timber Press, Portland

McDowall RM (1997) The evolution of diadromy in fishes (revisited) and its place in phylogenetic analysis. Rev Fish Biol Fish 7:443462

McKenzie DJ, Cataldi E, Di Marco P, Mandich A, Romano P, Ansferri S, Bronzi P, Cataudella S (1999) Some aspects of osmotic and ionic regulation in Adriatic sturgeon Acipenser naccarii. II: morpho-physiological adjustments to hyperosmotic environments. J Appl Ichthyol 15:61-66

Mizuno S, Ura K, Okubo T, Chida Y, Misaka N, Adachi S, Yamauchi $\mathrm{K}$ (2000) Ultrastructural changes in gill chloride cells during smoltification in wild and hatchery-reared masu salmon Oncorhynchus masou. Fish Sci 66:670-677

Morgan JD, Iwama GK (1998) Salinity effects on oxygen consumption, gill $\mathrm{Na}^{+}, \mathrm{K}^{+}$-ATPase and ion regulation in juvenile coho salmon. J Fish Biol 53:1110-1119

Moyle PB (2002) Inland Fishes of California. University of California Press, Berkeley

Nagashima K, Ando M (1994) Characterization of esophageal desalinisation in the seawater eel, Anguilla japonica. J Comp Physiol B 164:47-54

Nakamoto RJ, Kisanuki TT, Goldsmith GH (1995) Age and growth of Klamath River green sturgeon (Acipenser medirostris). U.S. Fish and Wildlife Service, Klamath River Fishery Resource Office, Yreka, p 20

Nebel C, Negre-Sadargues G, Blasco C, Charmantier G (2005) Morphofunctional ontogeny of the urinary system of the European sea bass Dicentrarchus labrax. Anat Embryol 209:193-206

Nielsen C, Madsen SS, Bjornsson BT (1999) Changes in branchial and intestinal osmoregulatory mechanisms and growth hormone levels during smolting in hatchery-reared and wild brown trout. J Fish Biol 54:799-818

Ojeda JL, Icardo JM, Domezain A (2003) Renal corpuscle of the sturgeon kidney: an ultrastructural, chemical dissection, and lectin-binding study. Anat Rec 272A:563-573

Parmelee JT, Renfro JL (1983) Esophageal desalination of seawater in flounder: role of active sodium transport. Am J Physiol 245:R888-R893
Penefsky HS, Bruist MF (1984) Adenosinetriphosphatases. In: Bergmeyer HU, Bergmeyer J, Grabl M (eds) Methods of enzymatic analysis. Verlag Chemie, Weinheim, pp 324-335

Pisam M, Rambourg A (1991) Mitochondria-rich cells in the gill epithelium of teleost fishes an ultrastructural approach. Int Rev Cytol 130:191-232

Pisam M, Prunet P, Boeuf G, Rambourg A (1988) Ultrastructural features of chloride cells in the gill epithelium of the Atlantic salmon Salmo salar and their modifications during smoltification. Am J Anat 183:235-244

Radaelli G, Domeneghini C, Arrighi S, Francolini M, Mascarello F (2000) Ultrastructural features of the gut in the white sturgeon, Acipenser transmontanus. Histol Histopathol 15:429-439

Richards JG, Semple JW, Bystriansky JS, Schulte PM (2003) $\mathrm{Na}^{+} /$ $\mathrm{K}^{+}$-ATPase $\alpha$-isoform switching in gills of rainbow trout (Oncorhynchus mykiss) during salinity transfer. J Exp Biol 206:4475-4486

Rodriguez A, Gallardo MA, Gisbert E, Santilari S, Ibarz A, Sanchez J, Castello-Orvay F (2002) Osmoregulation in juvenile Siberian sturgeon (Acipenser baerii). Fish Physiol Biochem 26:345-354

Sardella BA, Kültz D (2008) Osmo- and ionoregulatory responses of green sturgeon (Acipenser medirostris) to salinity acclimation. J Comp Physiol B 179:383-390

Scott GR, Baker DW, Schulte PM, Wood CM (2008) Physiological and molecular mechanisms of osmoregulatory plasticity in killifish after seawater transfer. J Exp Biol 211:2450-2459

Seidelin M, Madsen SS, Blenstrup H, Tipsmark CK (2000) Timecourse changes in the expression of $\mathrm{Na}^{+}, \mathrm{K}^{+}$-ATPase in gills and pyloric caeca of brown trout (Salmo trutta) during acclimation to seawater. Physiol Biochem Zool 73:446-453

Shehadeh ZH, Gordon MS (1969) The role of the intestine in salinity adaptation of the rainbow trout, Salmo gairdneri. Comp Biochem Physiol 30:397-418

Smith PK, Krohn RI, Hermanson GT, Mallia AK, Gartner FH, Provenzano MD, Fujimoto EK, Goeke NM, Olson BJ, Klenk DC (1985) Measurements of protein using bicinchoninic acid. Anal Biochem 150:76-85

Sundell K, Jutfelt F, Agustsson T, Olsen R-E, Sandblom E, Hansen T, Bjornsson BT (2003) Intestinal transport mechanisms and plasma cortisol levels during normal and out-of-season parrsmolt transformation of Atlantic salmon, Salmo salar. Aquaculture 222:265-285

Taylor JR, Grosell M (2006) Evolutionary aspects of intestinal bicarbonate secretion in fish. Comp Biochem Physiol A 143:523-529

Uchida K, Kaneko T (1996) Enhanced chloride cell turnover in the gills of chum salmon fry in seawater. Zool Sci 13:655-660

Uchida K, Kaneko T, Yamauchi K, Hirano T (1996) Morphometrical analysis of chloride cell activity in the gill filaments and lamellae and changes in $\mathrm{Na}^{+}, \mathrm{K}^{+}$-ATPase activity during seawater adaptation in chum salmon fry. J Exp Zool 276:193-200

Usher ML, Talbot C, Eddy FB (1991) Intestinal water transport in juvenile Atlantic salmon (Salmo salar L.) during smolting and following transfer to seawater. Comp Biochem Physiol A 100:813-818

Van Eenennaam JP, Webb MAH, Deng X, Doroshov SI, Mayfield RB, Cech JJ Jr, Hillemeier DC, Willson TE (2001) Artificial spawning and larval rearing of Klamath River green sturgeon. Trans Am Fish Soc 130:159-165

Varsamos S, Diaz JP, Charmantier G, Flik G, Blasco C, Connes R (2002) Branchial chloride cells in sea bass (Dicentrarchus labrax) adapted to fresh water, seawater, and doubly concentrated seawater. J Exp Zool 293:12-26

Veillette PA, Young G (2004) Temporal changes in intestinal $\mathrm{Na}^{+}$, $\mathrm{K}^{+}$-ATPase activity and in vitro responsiveness to cortisol in juvenile chinook salmon. Comp Biochem Physiol 138:297-303 
Veillette PA, White RJ, Specker JL (1993) Changes in intestinal fluid transport in Atlantic salmon (Salmo salar L.) during parr-smolt transformation. Fish Physiol Biochem 12:193-202

Veillette PA, Sundell K, Specker JL (1995) Cortisol mediates the increase in intestinal fluid absorption in Atlantic salmon during parr-smolt transformation. Gen Comp Endocrinol 97:250-258

Veillette PA, White RJ, Specker JL, Young G (2005) Osmoregulatory physiology of pyloric ceca: regulated and adaptive changes in Chinook salmon. J Exp Zool 303A:608-613

Walsh P, Danulat E, Mommsen TP (1991) Carbonate deposits in marine fish intestines: a new source of biomineralization. Limnol Oceangr 36:1227-1232

Wilson RW (1999) A novel role for the gut of seawater teleosts in acid-base balance. In: Egginton S, Taylor EW, Raven JA (eds) Regulation of acid-base status in animals and plants, SEB Seminar Series, vol 68. Cambridge University Press, Cambridge, pp 257-274

Wilson JM, Laurent P (2002) Fish gill morphology: inside out. Can J Zool A 293:192-213
Wilson RW, Gilmour KM, Henry RP, Wood CM (1996) Intestinal base excretion in the seawater-adapted rainbow trout: a role in acid-base balance? J Exp Biol 199:2331-2343

Wilson RW, Wilson JM, Grosell M (2002) Intestinal bicarbonate secretion by marine teleost fish-why and how? Biochim Biophys Acta 1566:182-193

Wright PA (2007) Ionic, osmotic, and nitogenous waste regulation. In: McKenzie DJ, Farrell AP, Brauner CJ (eds) Primitive fishes, Fish physiology series v.26. Academic Press, San Diego, pp 283-318

Zydlewski J, McCormick SD (1997) The ontogeny of salinity tolerance in the American shad, Alosa sapidissima. Can J Fish Aquat Sci 54:182-189

Zydlewski J, McCormick SD (2001) Developmental and environmental regulation of chloride cells in young American shad, Alosa sapidissima. J Exp Zool 290:73-87 